\title{
Biomass gasification for bioenergy
}

Puig Arnavat, Maria; Thomsen, Tobias Pape; Sárossy, Zsuzsa; Gadsbøll, Rasmus Østergaard; Clausen, Lasse Røngaard; Ahrenfeldt, Jesper

Published in:

Achieving Carbon-Negative Bioenergy Systems from Plant Materials

DOI:

10.19103/AS.2019.0027.04

Publication date:

2020

Document Version

Peer reviewed version

Citation for published version (APA):

Puig Arnavat, M., Thomsen, T. P., Sárossy, Z., Gadsbøll, R. Ø., Clausen, L. R., \& Ahrenfeldt, J. (2020). Biomass gasification for bioenergy. In C. Saffron (Ed.), Achieving Carbon-Negative Bioenergy Systems from Plant Materials Burleigh Dodds Science Publishing Limited. Burleigh Dodds series in agricultural science Vol. 64 https://doi.org/10.19103/AS.2019.0027.04

\section{General rights}

Copyright and moral rights for the publications made accessible in the public portal are retained by the authors and/or other copyright owners and it is a condition of accessing publications that users recognise and abide by the legal requirements associated with these rights.

- Users may download and print one copy of any publication from the public portal for the purpose of private study or research.

- You may not further distribute the material or use it for any profit-making activity or commercial gain.

- You may freely distribute the URL identifying the publication in the public portal.

Take down policy

If you believe that this document breaches copyright please contact rucforsk@kb.dk providing details, and we will remove access to the work immediately and investigate your claim. 


\title{
Biomass gasification for bioenergy
}

Maria Puig-Arnavat, Technical University of Denmark, Denmark;

Tobias Pape Thomsen, Roskilde University, Denmark;

and Zsuzsa Sárossy, Rasmus Østergaard Gadsbøll, Lasse Røngaard Clausen and Jesper Ahrenfeldt, Technical University of Denmark, Denmark

\begin{abstract}
Thermal gasification is a very relevant technological platform to assess in relation to production of carbonnegative bioenergy from plant materials as it offers high feed and product flexibility combined with highenergy efficiency. Many different biomass feedstock and organic secondary resources can be converted into a wide variety of products such as heat, electricity, chemicals, transport fuels and high-value ash and char products. The platform is undergoing fast development, and industry and academia work together to optimize the process performance, increase fuel and product flexibility as well as combine different technologies to increase the efficiency, economic viability and product yield and value. This chapter provides insight on the versatility and potential benefits of biomass gasification and the related biobased products. General key issues of gasification plant designs are discussed, and a series of new concepts and solutions within process integration schemes, polygeneration strategies and biochar uses are described.
\end{abstract}

Keywords: biomass, gasification, synfuel, syngas, biochar, ash, bio-oil

1 Introduction

2 Fundamentals of biomass gasification

3 Biomass gasification for heat and power generation

4 Fuel synthesis from biomass gasification synthesis gas

5 Carbon balance value of by-products from thermal gasification of biomass

6 System integration for polygeneration

7 Conclusion

8 Where to look for further information

9 References 


\section{Introduction}

Gasification is a partial thermal oxidation of carbon-rich materials yielding a non-condensable gas product $\left(\mathrm{CO}_{2}, \mathrm{CO}, \mathrm{H}_{2}, \mathrm{H}_{2} \mathrm{O}\right.$ and other gaseous hydrocarbons) and smaller quantities of by-products such as char, ash and condensable fractions including water, tars and oils. Biomass gasification platforms are most commonly designed for conversion of wood in the form of wood pellets, wood chips or waste wood. However, it is possible to extend the potential range of organic material fractions converted in thermal gasification to cover various organic secondary resources. This includes agricultural, municipal and industrial by-products and residues such as cereal straw, fibre residues, sludge and organic waste fractions.

Biomass-based energy systems have a unique potential for genuine carbon-negative energy production. There are two main routes that may be pursued individually or in a complementary combination: (i) combination with carbon capture and storage (CCS) and (ii) processes with co-production of carbon-rich char/ash fractions as well as other by-products to replace current, fossil-based products in the market. CCS has a huge potential, but the technology has to mature and the economic feasibility needs to improve for it to penetrate market barriers (Álamo et al., 2018). The technical potential for carbon sequestration via bioenergy processes with carbon-rich residuals is smaller than via CCS, but it is cheaper, robust and readily applicable. The potential to produce carbon-negative energy in this way, arise from a combination of high net energy efficiency and a potential for carbon sequestration via the ash/char fraction as illustrated in Fig. 1. Emissions from peripheral unit processes and upstream inputs influence the net potential of this approach. The level of direct carbon negativity will be given by the amount of long-term sequestered carbon minus all emissions related to biomass fuel procurement and pre-treatment, production and use of utilities (water, chemicals, fuels) as well as the production and maintenance of the plant and peripheral systems (Thomsen et al., 2011).

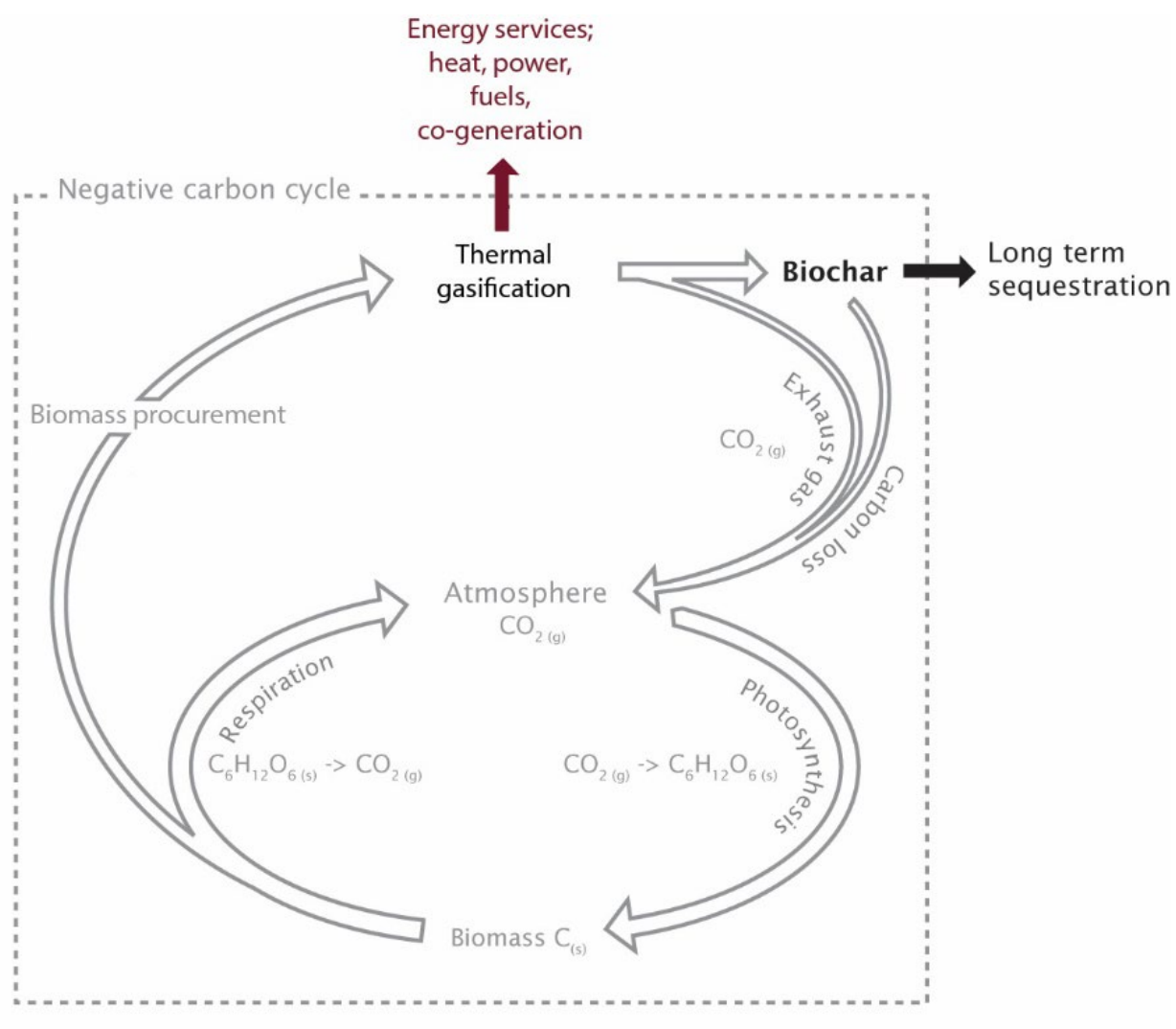

CARBON-NEGATIVE ENERGY PRODUCTION

Figure 1. Schematics of the ideal carbon-negative biomass-based CHP system. Adapted with permission from Thomsen et al. (2011). 
Additional contribution from downstream CCS added to this system will have a substantial potential to increase the level of carbon negativity. Even CCS processes with low coverage and/or efficiency may provide a sizable net contribution when combined with efficient low-carbon biomass-based energy systems. Systems with high net energy efficiency will have the highest abatement potential. In thermal systems, these are most often cases with utilization of the inevitable heat production, that is biomass-based heat systems or biomass-based co-generation systems. Thermal gasification of biomass is unique in this regard, since the platform excels in overall efficiency and flexibility.

Gasification is no new invention. First steps in the development of gasification started in the late 1600s. Hundred years later, in 1792, coal producer gas was reported to be used for lighting and later on for cooking and heating. Almost simultaneously, the water-gas-shift reaction was described and within a few decades, the first commercially used gasifier was built. Since the early 1900s, application of producer gas rapidly spread into power production, combined heat and power (CHP) production and operation of vehicle motors as well as into gasification of wood and other biomasses (Behera and Varma, 2019).

Despite the advantages that biomass gasification offers, it has not yet been able to consolidate its role and become a fully mature technology. Thus, a majority of biomass gasification projects remain at the pilot or demonstration scale. This is due to inherent challenges of biomass as a fuel and insufficient resources allocation to address operational issues related to the following (Asadullah, 2014a; Heyne et al., 2013; Sansaniwal et al., 2017; Zhang et al., 2013a):

- Supply chain management (transportation and storage due to low-energy density);

- Handling, pre-treatment and fuel feeding;

- Optimizing the energy efficiency to high moisture content feedstock;

- Addressing variations in biomass fuel properties;

- Unrealistic fuel flexibility expectations;

- Unrealistic product property expectations;

- Upscaling of specific gasifier reactors;

- Problems with gas cleaning, conditioning and impurities such as sulphur compounds (e.g. $\mathrm{H}_{2} \mathrm{~S}$, COS), hydrogen chloride, alkali and ammonia;

- Tar-related issues, for example condensation at lower temperatures which can lead to fouling and plugging of the plant pipelines, filters, catalyst units or engines; and

- Ash-related problems such as sintering, agglomeration, deposition, erosion and corrosion.

There is a firm belief in academia and industry that all mentioned technical problems can be overcome and that most of the solutions already exist. However, the foremost barrier for biomass gasification is associated with the economic risk in a rapidly changing energy market. Thus, policy measures ensuring long-term economic viability of the projects should be implemented.

The aim of this chapter was to provide an insight into the versatility and benefits of biomass gasification processes and its products in relation to production of carbon-negative bioenergy from plant-based materials. General key issues related to designing a gasification plant are reviewed and discussed, and several new concepts and solutions in the form of process integration schemes, polygeneration strategies and biochar uses are described. 


\section{Fundamentals of biomass gasification}

Biomass gasification involves a sequence of several stages occurring at different temperatures: drying (100$\left.200^{\circ} \mathrm{C}\right)$, pyrolysis $\left(200-700^{\circ} \mathrm{C}\right)$, partial combustion $\left(>800^{\circ} \mathrm{C}\right)$ and reduction or gasification $\left(700-900^{\circ} \mathrm{C}\right)$. These stages, depending on the specific gasifier design, often overlap.

- Drying: Evaporation of the moisture contained in the feedstock. The amount of heat required in this stage is proportional to the feedstock moisture content. The drying often takes place as a preliminary step in the pyrolysis stage and the required heat for both sets of processes is usually supplied from the oxidation stage.

- Pyrolysis: Thermal decomposition of biomass in the absence of oxygen/air. The cracking of chemical bonds takes place, resulting in the formation of molecules with a lower molecular weight. Thus, different fractions are obtained: solid char, liquid/condensed tars and a gaseous fraction. The condensable fraction of the pyrolysis gas will usually mix with the evaporated water from the drying stage as well as released cell bound water. Product weight and energy ratios will depend on the nature of the biomass, the reactor design and operating conditions of the process. Pyrolysis is a net endothermic stage and the heat required comes from the oxidation stage of the process.

- Oxidation: Usually, gasification involves a stage with partial oxidation to provide heat for the drying, pyrolysis and char gasification. During the partial oxidation, a part of the organic material in the fuel is oxidized and heat is released from the net exothermic reactions in the process. A partial oxidation is conducted by supplying, for example, air or pre-heated air to the gas/tar or to the char in a substoichiometric ratio.

- Reduction or gasification: During the reduction/gasification step, the carbon matrix of the pyrolysis char is decomposed by reaction with gasification agents $\mathrm{CO}_{2}$ and/or $\mathrm{H}_{2} \mathrm{O}$ at elevated temperatures under a reducing atmosphere leading to formation of combustible gases. The gas from pyrolysis and char gasification can be mixed subsequently or prior to the char gasification stage. The reduction step is endothermic, and the temperature at which it takes place has a fundamental role in determining the composition of the final gas and its characteristics (LHV, tar presence).

The quality of the gas produced in biomass gasification varies according to the gasifying agent used, the feedstock, bed material, operational conditions (temperature, pressure, air-to-fuel ratio) and gasification technology.

\subsection{Biomass resources}

Biomass is a broad concept that includes 'the biodegradable fraction of products, waste and residues of biological origin from agriculture (including vegetal and animal substances), forestry and related industries, including fisheries and the aquaculture as well as the biodegradable fraction of industrial and municipal wastes' (2009/28/EC European Directive). Even though gasification platforms are often designed for conversion of conventional biomass types, primarily wood, the global increase in demand for bioenergy has facilitated growing efforts to extend the potential range of organic material fractions converted in thermal processes. As a result, there is a growing focus on thermal utilization of various secondary organic resources including: (Thomsen et al., 2016):

- Agricultural by-products and residues: For example, crop residues (stalk, leaf, cob etc.), manure fibres, muck and bedding and fibres from biogas slurry; 
- Municipal by-products and residues: For example, source segregated organic waste, used textiles, grass and cuttings from road and park maintenance, beach cleaning waste and sewage sludge;

- Industrial by-products and residues: For example, residues from breweries, food packaging, food retail, food preparation or residues from production of non-food products based on the partial conversion of animal and vegetable raw materials.

Optimized treatment of secondary resources has great potentials from an economic, environmental and resource political point of view (Thomsen et al., 2016). However, the diversity of biomass resources makes it essential to characterize them thoroughly, as their physical-chemical properties will have a direct impact on the design of the gasification plant as well as on the technical and economic feasibility of the process. This characterization should be carried out before choosing the gasification technology to avoid subsequent problems. The biomass properties that have the highest impact on gasification technology are:

- Biomass particle size (Molino et al., 2018; Sansaniwal et al., 2017; Sikarwar et al., 2016):

Reducing the biomass particle size increases the pre-treatment cost of the feedstock, but it increases the surface area and decreases the diffusion resistance. This results in improved heat and mass transfer, increased reaction rates, fuel conversion, carbon conversion efficiency and decreased char and tar yields. Conventional gasifiers can take particle sizes in the range of $0.15-51 \mathrm{~mm}$. Particles of $0.15 \mathrm{~mm}$ are required for entrained flow gasifiers while fixed-bed reactors, with longer residence times, can tolerate particles up to $51 \mathrm{~mm}$. Usually, bubbling fluidized-bed (BFB) reactors can take particles of up to $6 \mathrm{~mm}$.

- Moisture content (Molino et al., 2016, 2018; Ruiz et al., 2013; Sansaniwal et al., 2017; Sikarwar et al., 2016): High moisture contents increase the energy required for water evaporation and steam gasification reactions that, in turn, may lower the gasifier operating temperature especially in the first stages. Reducing the moisture content may in some cases increase the energy efficiency, especially if low-temperature heat cannot be utilized. In addition, a dryer fuel will increase syngas quality, syngas HHV and decrease the conversion emissions. Fluctuations in biomass moisture content lead to variations in bed temperature, and this causes changes in the composition of the syngas generated.

The required moisture content of the biomass depends on the gasifier design; updraft fixed-bed gasifiers can operate with moisture contents up to $60 \%(\mathrm{w} / \mathrm{w})$, while downdraft fixed gasifiers can take maximum moisture contents of $25 \%(\mathrm{w} / \mathrm{w})$. However, values around $10-20 \%(\mathrm{w} / \mathrm{w})$ are generally recommended for conventional gasification technologies and will keep bed temperatures moderately stable.

- Ash content (Molino et al., 2018; Sansaniwal et al., 2017; Sikarwar et al., 2016): The ash content in biomass plays a significant role in thermal biomass utilization, especially if it contains alkali metals such as potassium or halides such as chlorine. Slagging, fouling and corrosion are important - and potentially critical, issues that may be caused by the inorganic species present in the biomass. It is not possible to give any general biomass criteria related to ash content as the potential problems relate to a combination of process design, process temperature profile, ash quantity and ash composition. However, generally, biomass with ash content lower than $2 \%(\mathrm{w} / \mathrm{w})$ can be used as feedstock material in all types of gasifiers even though there may still be issues related to corrosion and long-term deposit build-up.

- Bulk density: Bulk density will have a strong influence on the transportation costs, handling and feeding of the biomass in the gasification plant. Biomass with a low bulk density might cause severe 
feeding problems to the gasification units because of getting stuck in the feeding line. These problems can be overcome by densifying the bulky biomass; however, this will result in higher energy consumption and cost.

Organic resources that are initially found to be unsuited for thermal gasification may still have a fuel potential through fuel design or thermal pre-treatment. Torrefaction is a well-known process used to pre-treat biomass resources for various purposes and may render organic material more coal like. Many other problematic issues may be overcome by fuel design, for example through proper mixing. Recent studies on these issues have indicated many potential benefits related to moisture content, ash melting-related issues and ash/char by-product quality (Skoglund et al., 2016; Thomsen et al., 2016; Thomsen et al., 2017b; Thomsen et al., 2017c).

\subsection{Types of gasifiers}

The design of a biomass gasifier depends ideally on the fuel characteristics (size, shape, moisture content, ash content) and the marketability of the end products. The principal design concepts, even though there are others available, can be classified in fixed beds, fluidized beds and entrained flow reactors (Table 1).

Fixed-bed reactors are often considered the best choice for small-scale plants of up to $10 \mathrm{MW}$. Within fixedbed reactors, it is possible to distinguish updraft and downdraft configurations. In updraft gasifiers, the biomass is supplied from the top and the gasifying agent from the bottom (counter-current). For these gasifiers, the sequence for biomass is drying $\rightarrow$ pyrolysis $\rightarrow$ reduction $\rightarrow$ combustion. Instead, in downdraft gasifiers, the biomass and gasifying agent are supplied from the top (co-current). Thus, the sequence is drying $\rightarrow$ pyrolysis $\rightarrow$ combustion $\rightarrow$ reduction. The main difference is that in downdraft gasifiers the decomposition products from drying and pyrolysis go through thermal cracking in the oxidation zone, thus produce less tar and a higher-quality gas than updraft gasifiers, where the pyrolysis gas goes directly into the producer gas. Fixed-bed gasifiers are simple in construction and operate at low gas velocity with high carbon conversion and long residence time.

Fluidized-bed reactors, including BFB and circulating fluidized-bed (CFB) reactors, are based on the principle of fluidization in which both the fuel and the hot bed material (inert inorganic material and/or catalyst) is made to behave as a fluid by mixing the high-density bed and fuel material with a low-density fluidization agent, for example, air, steam or other gas. The semi-suspended conditions are kept by means of the gasifying agent added at the appropriate velocity. These gasifiers provide an excellent gas-solid mixing, a uniform temperature and solid/gas concentration in the entire bed. It is not possible to distinguish the different zones in single-reactor fluidized-bed systems (drying, pyrolysis, reduction and combustion) due to the intense gas-solid mixing. Fluidized-bed gasifiers usually operate at relatively low temperatures (700$900^{\circ} \mathrm{C}$ ) to prevent ash sintering and agglomeration and are the preferred option for large-scale plants due to superior scalability characteristics compared to fixed-bed systems.

Entrained flow reactors operate at high temperatures $\left(1400^{\circ} \mathrm{C}\right)$ and high pressure $(20-70$ bar) by injecting powdered fuel into a high-speed stream of the gasifying medium and into the reactor. Thus, the gas stream entrains the fuel particles and directs the flow direction and speed through the reactor system. 
Table 1. Comparison of different types of gasifiers (Basu, 2018; E4tech, 2009; Molino et al., 2016, 2018; Ruiz et al., 2013)

\begin{tabular}{|c|c|c|c|c|c|}
\hline Gasifier & Downdraft & Updraft & $\begin{array}{c}\text { Bubbling } \\
\text { fluidized bed }\end{array}$ & $\begin{array}{l}\text { Circulating } \\
\text { fluidized bed }\end{array}$ & $\begin{array}{c}\text { Entrained flow } \\
\text { bed }\end{array}$ \\
\hline Technology & \multicolumn{2}{|c|}{$\begin{array}{l}\text { Simple, reliable and proven. } \\
\text { Simple reactor with relatively } \\
\text { low investment cost }\end{array}$} & \multicolumn{2}{|c|}{$\begin{array}{l}\text { Plants with higher investment } \\
\text { and maintenance costs. Good } \\
\text { ability to scale-up }\end{array}$} & $\begin{array}{l}\text { Complex. High } \\
\text { investment and } \\
\text { maintenance } \\
\text { costs }\end{array}$ \\
\hline $\begin{array}{l}\text { Fuel } \\
\text { specifications }\end{array}$ & $<51 \mathrm{~mm}$ & $<51 \mathrm{~mm}$ & $<6 \mathrm{~mm}$ & $<6 \mathrm{~mm}$ & $<0.15 \mathrm{~mm}$ \\
\hline $\operatorname{Tar}\left(\mathrm{g} / \mathrm{Nm}^{3}\right)$ & $0.015-3.0$ & $30-150$ & $3.7-61.9$ & $4-20$ & $0.01-4$ \\
\hline $\begin{array}{l}\text { Ash and } \\
\text { particles in } \\
\text { syngas }\end{array}$ & Low & High & High & High & Low \\
\hline $\begin{array}{l}\text { Gasification } \\
\text { temperature }\end{array}$ & $900-1050^{\circ} \mathrm{C}$ & $950-1150^{\circ} \mathrm{C}$ & \multicolumn{2}{|c|}{$800-1000^{\circ} \mathrm{C}$} & $1300-1500^{\circ} \mathrm{C}$ \\
\hline $\begin{array}{l}\text { Syngas exit } \\
\text { temperature }\end{array}$ & $700^{\circ} \mathrm{C}$ & $150-400^{\circ} \mathrm{C}$ & \multicolumn{2}{|c|}{$800-1000^{\circ} \mathrm{C}$} & $>1260^{\circ} \mathrm{C}$ \\
\hline Capacity & $<5 \mathrm{MWe}$ & $<10 \mathrm{MWe}$ & $1-20 \mathrm{MWe}$ & $2-100 \mathrm{MWe}$ & 5-100 MWe \\
\hline $\begin{array}{l}\text { Carbon } \\
\text { conversion } \\
\text { efficiency }\end{array}$ & High & High & $\begin{array}{l}\text { High. Loss of } \\
\text { carbon in ash }\end{array}$ & High & High \\
\hline $\begin{array}{l}\text { Process } \\
\text { flexibility }\end{array}$ & \multicolumn{2}{|c|}{$\begin{array}{l}\text { Very limited. Any change in } \\
\text { the process variables needs a } \\
\text { new design }\end{array}$} & \multicolumn{2}{|c|}{$\begin{array}{c}\text { Flexible to loads less than } \\
\text { design }\end{array}$} & $\begin{array}{l}\text { Very limited. } \\
\text { Size and } \\
\text { energy content } \\
\text { of the fuel } \\
\text { must be in a } \\
\text { narrow range }\end{array}$ \\
\hline $\begin{array}{l}\text { Hot gas } \\
\text { efficiency }\end{array}$ & $85-90 \%$ & $90-95 \%$ & $89 \%$ & $89 \%$ & $80 \%$ \\
\hline
\end{tabular}

\subsection{Gasification operating variables}

The operating parameters such as temperature, pressure, gasifying agent and equivalence ratio (ER) will have a very important role in determining the gasification performance, syngas yield and gas composition.

\subsubsection{Temperature}

Temperature is a crucial parameter in biomass gasification which, to a large extent, controls the gas composition, reaction rate, tar concentration, ash-related problems and so forth. Low temperatures generally result in higher tar content and low $\mathrm{CO}$ and $\mathrm{H}_{2}$ content in the product gas. High-temperature gasification, on the other hand, leads to a desired high yield of $\mathrm{CO}$ and $\mathrm{H}_{2}$ while reducing the tar content. However, high gasification temperatures present two major potential drawbacks: ash-melting problems, especially for high ash-containing biomass, and rigorous reactor specifications. 


\subsubsection{Pressure}

Biomass gasification can be operated at atmospheric pressure or at higher pressures usually depending on the downstream application of the product gas. If the product gas is used in turbines or in Fischer-Tropsch synthesis, then pressurized gasification can be convenient even though it is more technologically complex. A reduction in the tar yield and in light hydrocarbons can be achieved by operation at higher pressures (Asadullah, 2014a; Molino et al., 2018).

\subsubsection{Gasifying agent}

Air, steam, pure oxygen, carbon dioxide or mixtures of them can be used as gasifying agents. The selection will depend on the gas quality requirements for the downstream applications and the economics of the overall process. Air is the cheapest and most cost-effective gasifying agent and has been extensively applied for heat and power generation purposes. It results in a highly nitrogen diluted and low-quality gas with low $\mathrm{H}_{2}$ content (8-14 vol. \%) and a heating value in the range of 4-7 MJ/ $\mathrm{Nm}^{3}$ (Matas Güell et al., 2012). Pure oxygen is the most expensive gasifying agent because it requires an air-separation unit, but it leads to a syngas with a heating value up to $28 \mathrm{MJ} / \mathrm{m}^{3}$, higher concentrations of $\mathrm{CO}, \mathrm{H}_{2}$ and low concentration of tars (Asadullah, 2014a; Molino et al., 2018). The cost of steam is somewhere between air and oxygen and leads to a product gas with a heating value around $10-18 \mathrm{MJ} / \mathrm{Nm}^{3}$ and with a higher concentration of $\mathrm{H}_{2}$ as a result of the water-gas-shift reaction, but it reduces the thermal efficiency of the gasification. Steam-only gasification requires an external energy supply due to the endothermic reactions involved in the process. $\mathrm{CO}_{2}$ gasification results in a product gas rich in $\mathrm{CO}$ because of the reaction of $\mathrm{CO}_{2}$ and carbon; however, this reaction is slow and external heat supply is required.

\subsubsection{Equivalence ratio (ER)}

The ER can be defined as the ratio between air-to-fuel ratio of the gasification process and the air-to-fuel ratio for complete stoichiometric combustion. ER is a relevant parameter because it defines the degree of combustion and, thus, the temperature and distribution of gas, tar and char in the gasifier. ER optimal values are in the range of $0.2-0.3$ for fixed-bed and fluidized-bed gasifiers, while entrained flow gasifiers usually require a 20\% higher ER (Molino et al., 2018). ER lower than 0.2 results in an incomplete gasification, while ER higher than 0.4 approach the combustion. Decreasing the ER results in higher concentrations of $\mathrm{H}_{2}$ and $\mathrm{CO}$ and higher calorific value of the product gas. Increasing the ER has the opposite effect and increases the $\mathrm{CO}_{2}$ concentration but it reduces the tar yield. Thus, it is necessary to optimize the process depending on the downstream applications.

\subsection{Synthesis gas requirements for further applications}

The gas produced from biomass gasification is rarely used directly in downstream applications. Usually the gas needs to be cooled and cleaned to ensure smooth and efficient operation. The gasifier design, feedstock type, gasifying agent and other operating parameters will influence the gas composition and the quantity and type of impurities. The gas quality is a key driver in the technical and economic feasibility of different application schemes. In Table 2, a range of generalized quality measures accepted by engine, gas turbine and fuel-cell applications are provided.

In fuel synthesis from gasification producer gas, the gas quality requirements may be even higher than for direct production of electricity and heat. The catalysts used in Fischer-Tropsch synthesis are sensitive to even very small amounts of impurities. In commercial operation, catalysts are replaced or regenerated after a certain operational period. Thus, the definition of the gas cleaning is therefore based on economic considerations: investment in gas cleaning versus accepting decreasing production due to poisoning of the 
catalyst. Requirements for feed gas quality of different downstream applications can be found elsewhere (Boerrigter et al., 2004; Molino et al., 2018; Tijmensen et al., 2002).

Table 2. Acceptable range of impurities for different applications (Hasler and Nussbaumer, 1999; Sansaniwal et al., 2017; Singh et al., 2014)

\begin{tabular}{|l|c|c|c|}
\hline & IC engine & Gas turbine & Fuel cell \\
\hline Particles $\left(\mathrm{mg} / \mathrm{Nm}^{3}\right)$ & $<50$ & $<30$ & - \\
\hline Particulate matter $(\mu \mathrm{m})$ & $<100$ & $<5$ & $<1$ \\
\hline Tar $\left(\mathrm{mg} / \mathrm{Nm}^{3}\right)$ & $<10$ & $<5$ & $<1$ \\
\hline Alkali metals $(\mathrm{mg} / \mathrm{Nm})$ & - & $<0.24$ & - \\
\hline
\end{tabular}

\subsection{Gas cleaning processes}

As previously mentioned, cleaning and conditioning of the product gas may be required to remove contaminants and potential catalyst poisons as well as to achieve the qualitative composition required by, for example, biofuel production processes. There are several papers available in the literature that have recently addressed and analysed the different possible cleaning processes (Abdoulmoumine et al., 2015; Asadullah, 2014b; Woolcock and Brown, 2013). In this section, a brief summary of commonly applied physical, thermal and catalytic gas cleaning technologies is presented.

\subsubsection{Physical gas cleaning}

Physical gas cleaning is one of the simplest cleaning methods and includes filtration and wet scrubbing to remove tar and particulate matter from the gas through gas/solid or gas/liquid interactions. Filtration can be conducted at high or low temperatures. High-temperature filtration requires temperature tolerable materials such as ceramics, fibre glass, composites or sand. Low-temperature filtration processes can use charcoal, cotton fibres as filtration media. Filtration techniques often face the problem of clogging and deposition of gas particles causing a pressure drop across the filtration. Back-flushing the filtration media with, for example, nitrogen may revitalize the performance of the filter.

Wet scrubbing is usually done at low or ambient temperature using water, oil or another solvent but faces the problem of producing high amounts of contaminated liquid that needs to be treated.

\subsubsection{Thermal gas cleaning}

Thermal decomposition consists of degrading (cracking) heavy aromatic tar compounds into smaller, lighter and non-condensable gas species such as methane, hydrogen and carbon dioxide at temperatures around $1000^{\circ} \mathrm{C}$. The most problematic aspects of high-temperature cracking relate to the required temperature resistance of the setup that needs a complex and highly controllable heating system and intensive cooling system for the gas afterwards as well as possible ash-melting-related problems (Asadullah, 2014a).

\subsubsection{Catalytic gas cleaning}

It is possible that physical and thermal gas cleaning steps are not enough to fulfil stringent requirements of some downstream applications. Thus, the utilization of effective catalysts is often considered a method to decrease the concentration of tar and ammonia in the product gas. Catalytic decomposition usually occurs at 
much lower temperatures $\left(600-800^{\circ} \mathrm{C}\right)$ than thermal cracking $\left(>1000^{\circ} \mathrm{C}\right)$. Catalysts for tar removal have been tested and used directly in the gasifier reactor as well as in secondary catalytic reactors. Sometimes, additional oxidant $\left(\mathrm{O}_{2}\right.$ or $\left.\mathrm{H}_{2} \mathrm{O}\right)$ is injected into the secondary catalytic bed. Tars can be cracked or hydrocracked into light hydrocarbons or converted into $\mathrm{CO}$ and $\mathrm{H}_{2}$ through steam and dry reforming reactions. The spectrum of studied catalytic materials covers acidic solids for cracking, basic solids for 'reforming' reactions and metal oxides with both acidic and metal sites for cracking and hydrocracking reactions (Torres et al., 2007). Desirable properties of a good catalyst for any of these reactions are (Sutton et al., 2001): (i) capability to efficiently convert tars into useful gas products in an environment containing high concentrations of $\mathrm{H}_{2}, \mathrm{CO}, \mathrm{CO}_{2}$ and $\mathrm{H}_{2} \mathrm{O}$ at temperatures of $600-800^{\circ} \mathrm{C}$ at ambient pressure (or even higher temperatures for pressurized reactors); (ii) resistance to deactivation and poisoning by species in the gas, such as sulphur-containing compounds; and (iii) resistance to attrition. It is also desirable to carry out the tar conversion process in such a way as to keep the deposition of carbonaceous materials on the catalyst surface under control.

In biomass gasification, most of the nitrogen ends up as ammonia $\left(\mathrm{NH}_{3}\right)$ and $\mathrm{N}_{2}$ with lower concentrations of hydrogen cyanide (HCN), isocyanic acid (HNCO) and nitrogen oxides (NOx). Nitrogen-containing species are undesirable because they can poison catalysts or serve as precursors for NOx in downstream burners, gas engines or gas turbines. Most of the literature on the removal of ammonia refers to the use of calcined dolomite, nickel and iron catalysts, the same catalysts used for tar decomposition reactions. 


\section{Biomass gasification for heat and power generation}

Biomass gasification for production of power or CHP is currently the most widely applied use of the technology. In recent studies on the status of biomass gasification in EU, it was found that almost 900 biomass gasifiers are currently in operation. In Germany alone, almost 400 biomass gasifiers have been identified. The majority of the systems are small-scale wood gasifiers build for CHP production in integrated gas engines with power production capacities averaging around $80 \mathrm{~kW}$ power per unit. The dominating manufacturer is Burkhardt who produces CHP gasifiers with approximately $30 \%$ electrical efficiency operated on wood pellets (Böcker-Riese and Bräkow, 2017; Hrbek, 2016).

However, large-scale facilities for biomass gasification and production of heat and power also exist, even though number and total capacity is limited. In a report on large-scale biomass applications from IEA task 40 from 2013, it was found that the ten largest biomass and waste gasifiers in Europe constituted approximately 600 MW thermal capacity in total, ranging from 160 to 20 MW thermal capacity. During 2012, the ten plants converted approximately $9 \mathrm{PJ}$ of biomass out of a total capacity potential of approximately $18 \mathrm{PJ}$ biomass. Most of the recent large-scale plants are built by the Finnish company Valmet, and in addition to the listed plants in Europe at least three other Valmet gasifiers are in operation in Indonesia and China. Additional biomass gasifiers are found in, for example, Cambodia (+35), Japan and the United States, but the aggregated capacity of these plants is limited (Shackley et al., 2012; Vakkilainen et al., 2013; Valmet, 2015).

As previously described, there are many different types of biomass gasifiers, and the application of the different systems is plentiful and innovative. Today, complete systems for production of heat and power as well as add-on systems for retrofitting the fossil fuel-based infrastructure exist.

The application of the biomass gasifier CHP system poses different possibilities and limitations to the design and operation. The following two systems can be used to illustrate two very different examples of this, that is as in Fig. 2: high efficiency, fully automatic small-scale wood gasification with integrated gas conversion or as in Fig. 3: retrofitting of existing coal-fired power plants with low-temperature gasification of low-value biogenic residues and wastes. These two opposing examples of biomass gasification for CHP production are described in more detail with case studies in the following.

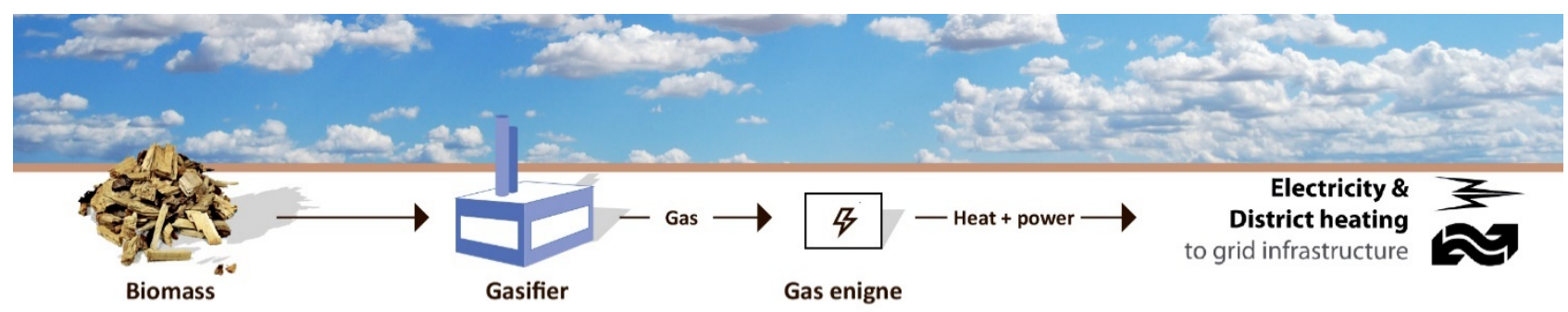

Figure 2. Illustration of a complete CHP setup with thermal gasification of biomass and conversion of the producer gas in a gas engine, full cell or gas turbine. 


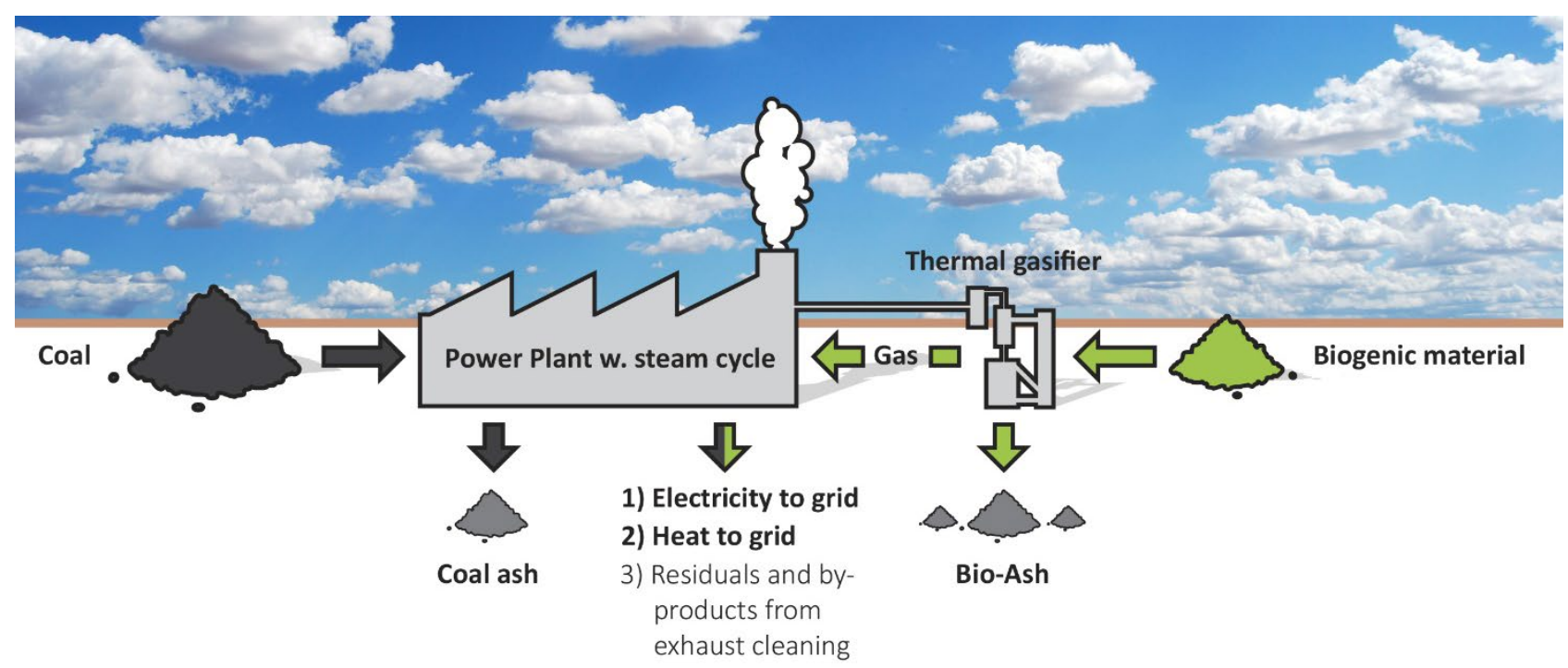

Figure 3. Illustration of a gasification system for retrofitting existing fossil fuel-powered steam cycles with medium- to large-scale thermal gasification of biomass.

\subsection{Case studies}

Three cases with very different biomass gasifiers in CHP systems are presented to illustrate the variety in design and application. Many more cases can be studied by addressing previously published literature on this issue (Ahrenfeldt et al., 2013a; Behera and Varma, 2019; Brandin et al., 2011; Sikarwar et al., 2016). The three cases are as follows:

\subsubsection{Case study 1: Product flexibility: The TwoStage Downdraft Gasifier}

The Biomass Gasification Group, at the Technical University of Denmark, has been working with staged gasification in fixed beds since 1989. This has led to the development of the two-stage downdraft concept originally designed for gasification of wet wood chips in plants of up to $2 \mathrm{MW}$ thermal capacity. The twostage process encompasses pyrolysis and gasification in two separate reactors with an intermediate hightemperature tar conversion zone. This staged design allows for efficient temperature control, and combined with catalytic tar cracking in the char bed of the gasification reactor, the intermediate thermal tar cracking leads to extremely low tar concentrations in the produced gas (Ahrenfeldt et al., 2006; Ahrenfeldt et al., 2013a; Henriksen et al., 2006). An illustration of the two-stage process is provided in Fig. 4.

The two-stage downdraft gasifier has been built in several different sizes from $50 \mathrm{~kW}$ to $1.5 \mathrm{MW}$ thermal capacity. Different designs have been investigated, and currently alternative reactor designs are considered to allow for scaling up the plant (Ahrenfeldt et al., 2013b; Gadsbøll, 2018). The system is designed for automatic, unmanned operation and has achieved more than $4000 \mathrm{~h}$ of operation (more than 3500 with engine operation). The producer gas from this unit is very clean and the high quality allows for multiple uses of the gas in CHP systems with Solid Oxide fuel cells as well as gas engines or for production of liquid or gaseous fuels as described later (Gadsbøll et al., 2017).

In recent years, the fuel flexibility of the two-stage downdraft design has been tested and additional relevant fuel candidates identified. Current focus of the technology is therefore expanded to include smaller energy island systems in rural areas of developing countries in Africa and Asia. 


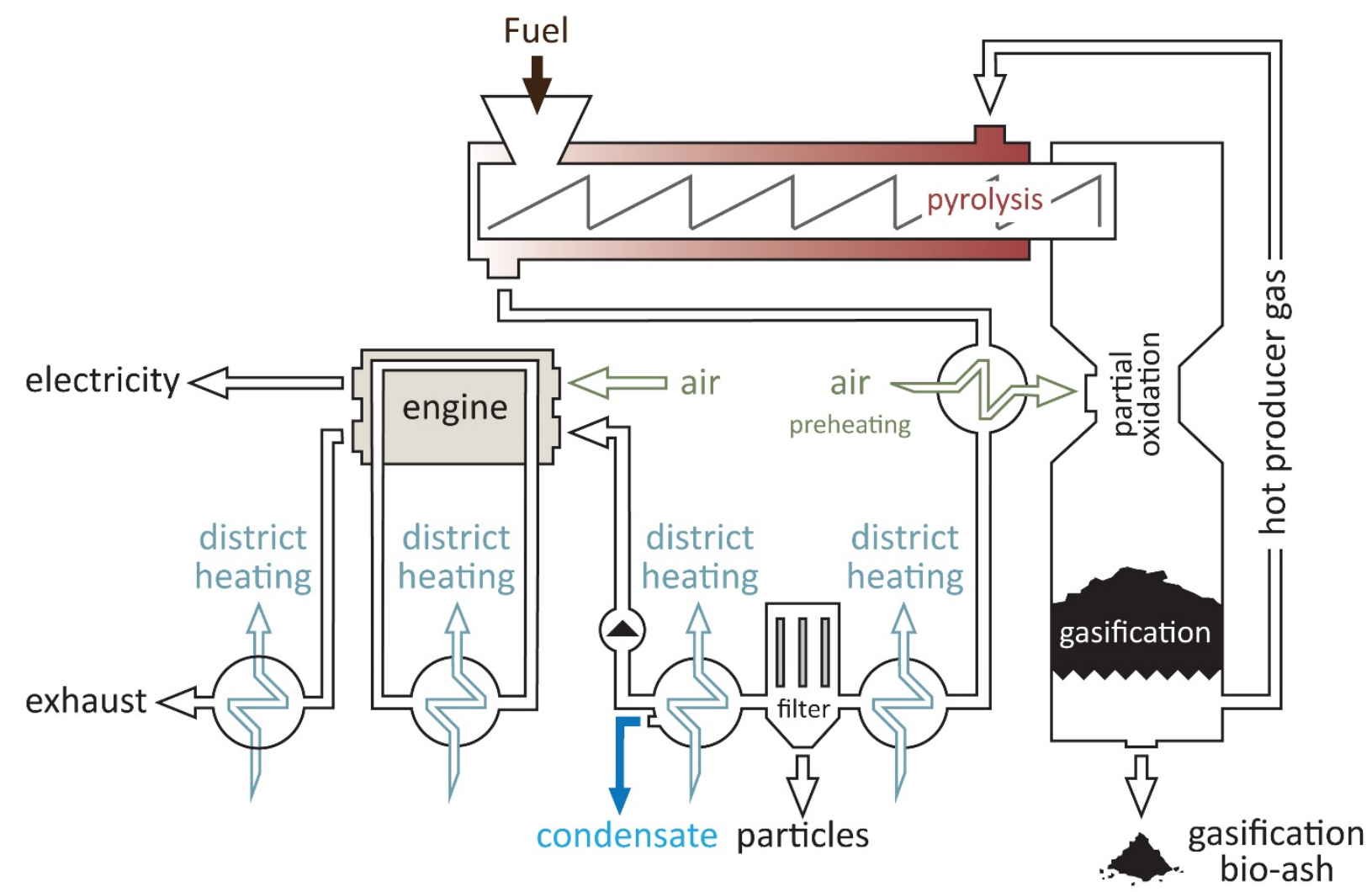

Figure 4. Simplified illustration of a two-stage downdraft gasifier. Adapted with permission from Ahrenfeldt et al. (2013a).

\subsubsection{Case study 2: Operational stability: The Harboøre updraft gasifier}

Celebrating 25 years of operation in 2018, the oldest biomass gasifier in operation today is the Harboøre 5.2 MW (thermal capacity) fixed-bed updraft gasifier. The plant went into operation in 1993, and in 2010, it had already operated for more than 110,000 h (Brandin et al., 2011; Heeb, 2010). In year 2000, the plant was upgraded with two Jenbacher gas engines for CHP production, and 10 years later, the engines had operated for more than 70,000 h each (Brandin et al., 2011; FORCE technology, n.d.).

The CHP plant in Harboøre is an air-blown updraft gasifier converting wood chips into producer gas, which is converted into heat and power in two gas engines after conditioning. The primary conditioning step is gas cooling and subsequent removal of water and tars in an electrostatic precipitation filter. The removed tar is stored and used for peak load situations in the heat demand by combusting the tar in adjacent boilers. The plant is designed for unattended operation, and holds a record in most hours of unattended operation of a biomass gasification plant. Unmanned operation and low downtime is possible due to extremely stable operation, which is an essential parameter for commercial CHP production (Jesper Ahrenfeldt et al., 2013a; Brandin et al., 2011; FORCE technology, n.d.).

\subsubsection{Case study 3: Fuel flexibility: The Low Temperature Circulating Fluidized Bed (LT-CFB) gasifier}

The low-temperature circulating fluidized-bed (LT-CFB) gasifier is a process developed by Danish Fluid Bed Technology A/S, the Biomass Gasification Group at the Technical University of Denmark and DONG Energy A/S (now Ørsted A/S). The technology has been under development for almost 20 years and is today commercialized under the registered alias Pyroneer. The LT-CFB process and operation has been described 
several times in previously published articles (Narayan et al., 2016; Nguyen et al., 2013; Stoholm et al., 2002, 2007; Thomsen et al., 2015; Zwart et al., 2010) and an illustration of the central reactor construction is provided in Fig. 9.

The LT-CFB gasifier was originally developed for pre-processing of cereal straw in CHP systems based on dust-fired coal boilers. In popular terms, the LT-CFB separates the inorganic material from the organic fraction of the straw. The inorganic material is extracted in one or several different ash fractions, and the organic material is converted into a hot combustible gas product, which is subsequently combusted in an adjacent boiler. A 6 MW unit was installed, in 2014, at the Danish power plant Asnæsværket in Kalundborg to convert straw and other biomass residues and supply a hot combustible gas to the boilers of unit 2 to substitute coal. After numerous successful campaigns in the following years, the technology development has been put on hold while the company's (Ørsted) focus is on offshore wind power.

Today, the Finnish company Valmet is the main commercial actor within development and production of plants for biomass gasification and subsequent gas combustion in adjacent boilers. Valmet has gathered profound experience and expertise within CFB systems and retrofitting as well as gas combustion in new boilers. Recent tests have shown than retrofitted coal boilers may run exclusively on biomass producer gas as well as with a combination of producer gas and coal dust (Valmet, 2015, n.d.). Table 3 provides a set of CHP data of the three different cases of biomass gasification plants presented previously.

Table 3. Plant data estimations of three different types of biomass gasification plants for combined heat and power production. Using data from real plants or present state-of-the-art estimates (Ahrenfeldt et al., 2013a; Energistyrelsen and Energinet.dk, 2012; FORCE technology, n.d.)

\begin{tabular}{|c|c|c|c|c|}
\hline Parameter & Unit & $\begin{array}{l}\text { Staged, downdraft } \\
+ \text { IC gas engine }\end{array}$ & $\begin{array}{l}\text { Updraft fixed bed }+ \\
\text { IC gas engine }\end{array}$ & $\begin{array}{l}\text { Pre-gasifier } \\
\text { for boilers }\end{array}$ \\
\hline $\begin{array}{l}\text { Maximum thermal } \\
\text { capacity per unit }\end{array}$ & $\begin{array}{l}\text { MW thermal } \\
\text { input }\end{array}$ & 1.5 & 5 & 100 \\
\hline $\begin{array}{l}\text { Efficiency, fuel to hot } \\
\text { gas }\end{array}$ & $\%$ of fuel energy & - & - & 95 \\
\hline $\begin{array}{l}\text { Net efficiency, fuel to } \\
\text { heat }\end{array}$ & $\%$ of fuel energy & 55 & 55 & $\begin{array}{l}\text { Depend on } \\
\text { boiler }\end{array}$ \\
\hline $\begin{array}{l}\text { Net efficiency, fuel to } \\
\text { power }\end{array}$ & $\%$ of fuel energy & $35-40$ & $28-32$ & $\begin{array}{l}\text { Depend on } \\
\text { boiler }\end{array}$ \\
\hline Technical lifetime & Years & $15-20$ & 20 & 25 \\
\hline Construction time & Years & 1 & 1.5 & 2 \\
\hline Investment costs & $\begin{array}{c}\text { Million } € \text { per } \\
\text { MW }_{\mathrm{TH}}\end{array}$ & $3.4-3.7$ & 3.7 & $0.3-0.5$ \\
\hline $\begin{array}{l}\text { Operation and } \\
\text { maintenance costs }\end{array}$ & $€$ per $\mathrm{MWh}_{\mathrm{TH}}$ & $\begin{array}{c}18+69000 € \text { per } \\
\text { MW per year }\end{array}$ & $\begin{array}{c}19+185000 € \text { per } \\
\text { MW per year }\end{array}$ & 2.4 \\
\hline
\end{tabular}

$\mathrm{TH}=$ Thermal input. 


\section{Fuel synthesis from biomass gasification synthesis gas}

\subsection{The Fischer-Tropsch process for hydrocarbon production}

The Fischer-Tropsch (FT) process is a set of chemical reactions that convert carbon monoxide and hydrogen (synthesis gas) into liquid hydrocarbons. The reaction was invented and developed by Franz Fischer and Hans Tropsch in 1925 in Germany, although the fuel production first started in 1935 at the Ruhrchemie Company. Industrial interest in the reaction fluctuated due to the changes in availability and price of oil. As the demands for environmentally friendly fuels are increasing, interest in FT synthesis is growing as well, and the technology gains attention to produce liquid fuels from natural gas, coal and biomass (Fechete and Vedrine, 2017; Krylova, 2014; Samavati, 2018). Bio-derived synthetic hydrocarbons from synthesis gas offers a cleaner and more sustainable solution compared to fossil alternatives, with significantly reduced greenhouse gas emissions (GHGs) and net climate impact. The hydrocarbons produced by the FT reactions may be used as liquid fuels such as gasoline, diesel and jet fuel or as building block chemicals, such as lower olefins. Today, technological platforms exist that use FT synthesis in conversion of various carbon-rich materials into liquid fuels including coal to liquid (CTL), biomass to liquid (BTL), gas to liquid (GTL) and waste to liquid (WTL; Krylova, 2014; Maitlis, 2013; Williams et al., 2011; Zhang et al., 2013b). Large-scale BTL plants are very scarce, hence product yields and process efficiencies are only estimated. Based on modelling studies, efficiencies in terms of chemical energy and carbon recovered in the produced hydrocarbons are in the range of $30-50$ and $25-45 \%$, respectively.

\subsubsection{Reaction mechanism, environment and catalysts}

The FT reactions, synthesis of hydrocarbons from $\mathrm{CO}$ and $\mathrm{H}_{2}$ is a complex catalytic process, including a great number of consecutive and parallel reactions. The reaction in a general form is showed in Eq. 1. FT synthesis is performed at normal or elevated pressures (typically $15-40 \cdot 10^{5} \mathrm{~Pa}$ ) with catalysts based on the Group VIII transition metals, mainly $\mathrm{Co}$ and $\mathrm{Fe}$ and to some extent also $\mathrm{Ni}$ and $\mathrm{Ru}$. Two main regimes are used: low-temperature Fischer-Tropsch $\left(200-250^{\circ} \mathrm{C}\right)$ results in long-chain molecules, and high-temperature Fischer-Tropsch $\left(320-375^{\circ} \mathrm{C}\right)$ gives shorter-chain molecules (Maitlis, 2013).

$\mathrm{CO}+2 \mathrm{H}_{2}=\left[-\mathrm{CH}_{2}-\right]+\mathrm{H}_{2} \mathrm{O}$

\subsubsection{Products via the Fischer-Tropsch reaction}

The Fischer-Tropsch synthesis can produce a wide range of long-chain hydrocarbon products, such as gasoline, synthetic naphtha, synthetic middle oil distillates (diesel and kerosene), lubricating oils and synthetic waxes (Fechete and Vedrine, 2017; Krylova, 2014). The produced hydrocarbons are typically a mix of straight-chain alkanes or paraffins. The reaction results in hydrocarbons with no oxygen content, leading to fine compatibility with the current engine and fuelling infrastructure (Bergthorson and Thomson, 2015). The lack of aromatic molecules in the FT fuels may lead to issues such as poor lubricity and seal-swell problems. The reduced aromatic content, however, is also an advantage, since aromatic content is associated with poorer combustion efficiency (increased $\mathrm{CO}$ and unburned hydrocarbon emissions) and increased soot emissions. Biomass-derived FT fuels have essentially zero sulphur content, reduced amounts of other contaminants and extremely low amounts of air pollutants leave the plants (Liu et al., 2011). The FT fuel products may be modified by isomerization processing to produce branched hydrocarbons for gasoline and jet-fuel applications, or to produce aromatics and naphthas, which could lead to renewable biojet fuels. A 
standard was made (ASTM 7566) that allows blends of up to $50 \%$ of synthetic hydrocarbon alternative jet fuels to be used when mixed with conventional commercial jet fuel, but at present only from specific feedstocks and processes (Bergthorson and Thomson, 2015).

When biomass is utilized via gasification, the produced synthesis gas can be converted to hydrocarbons with the FT process. The resulting liquid hydrocarbon fuels (mainly diesel and gasoline compounds), however, have a low octane number because of high concentrations of linear alkanes, hence they need upgrading for better properties (Galadima and Muraza, 2015).

\subsubsection{Use of $\mathrm{CO}_{2}$ in a Fischer-Tropsh reaction mechanism}

Great efforts are being invested to develop new and efficient technologies that will contribute to capture and convert $\mathrm{CO}_{2}$ into fuel materials and decrease the GHG levels as well. Transformation of $\mathrm{CO}_{2}$ into fuels and chemicals with renewable $\mathrm{H}_{2}$ via heterogeneous catalysis is a promising way to reach that goal; however, there are still great challenges before these processes can be commercialized and applied at a large scale. The catalytic reduction of $\mathrm{CO}_{2}$ by $\mathrm{H}_{2}$ can lead to the formation of three types of products: $\mathrm{CO}$ via a reverse watergas-shift (RWGS) reaction, methanol via selective hydrogenation and hydrocarbons via combining $\mathrm{CO}_{2}$ reduction with FT reactions. The CO intermediate produced by RWGS reactions offers a flexible solution, since $\mathrm{CO}$ can be used in both methanol synthesis and downstream FT for fuels and chemicals. Direct hydrogenation of $\mathrm{CO}_{2}$ can result in hydrocarbon formation, including both alkanes and olefins. Another route may be direct FT reactions from $\mathrm{CO}_{2}$ and $\mathrm{H}_{2}\left(\mathrm{CO}_{2}-\mathrm{FT}\right)$ by performing RWGS followed by FT in one reactor. The $\mathrm{CO}_{2}$-FT process is very attractive because this way alkanes and olefins can be directly converted from $\mathrm{CO}_{2}$ and $\mathrm{H}_{2}$, but finding appropriate catalysts is very challenging (Gao et al., 2018; Porosoff et al., 2016).

\subsubsection{Economic feasibility of Fischer-Tropsch using syngas from biomass gasification}

The FT process has been developed for decades; however, large-scale applications are scarce, especially when the syngas is based on biomass conversion. Large-scale, long-time investments of such plant developments are very risky due to the high capital costs, high operational and maintenance costs and even environmental concerns, so plant constructions have been often announced and then shut down or halted (Baliban et al., 2013; Maitlis, 2013; Venvik and Yang, 2017). There are different approaches for cheaper and more efficient plant installations, for example the so-called microstructured or microchannel reactors (also referred to as microreactors) showing enhanced heat and mass transfer in combination with highly active, selective and stable catalysts (Venvik and Yang, 2017). It has also been showed that the production of FT fuels is more profitable when electricity is generated as a co-product. The new plant designs should aim for producing ultraclean synthetic fuels from coal and lignocellulosic biomass combined with $\mathrm{CO}_{2}$ capture and storage (Liu et al., 2011).

\subsection{Methanol synthesis}

Methanol $\left(\mathrm{CH}_{3} \mathrm{OH}\right)$ has been a widely utilized substance in the chemical industry for many decades. It is very versatile and used for a variety of industrial products including production of olefins, formaldehyde and acetic acid, which are important industrial intermediates. The global consumption of methanol in 2017 was approximately $92 \mathrm{Mt} / \mathrm{year}$ (Dalena et al., 2018). It is a colourless, tasteless and poisonous substance that is liquid at ambient conditions and is easily stored. In recent years, there has been an increasing interest in methanol as a fuel, as it might act as an efficient renewable energy carrier (provided that it is produced from sustainable sources). The interest is especially centred around its abilities as a transport fuel for internal combustion engines. It can either be blended with gasoline or be used as a primary fuel. Converting the 
vehicle fleet to methanol will only require minimal modifications to existing technology. Other methanol applications include fuel-cell operation and hydrogen carriers.

Methanol synthesis has been commercial for about 90 years, initially with plants based on steam gasification of coal. Today, the primary source is natural gas that accounts for $90 \%$ of the production (Dalena et al., 2018). This process features steam reforming of natural gas up to the $\mathrm{GW}_{\text {th }}$-scale and the energy efficiency can be up to $69 \%$ (Danish Technological Institute, 2011). Methanol from biomass gasification is still in the developmental phase and, while there are technical solutions to the majority of challenges, there is still not a clear economic incentive to broadly commercialize the technology. There are, however, several pilot as well as early-commercial demo plants in operation (Molino et al., 2018). In relation to the natural gas-based efficiency, studies on methanol via biomass gasification have modelled efficiencies on the range of 55-59\% (Danish Technological Institute, 2011; Puerari et al., 2014; Røngaard Clausen, 2011) - the difference in efficiency to natural gas reforming is namely because of the gasification step.

The key reactions in methanol synthesis are:

$$
\begin{aligned}
& \mathrm{CO}+2 \mathrm{H}_{2} \rightarrow \mathrm{CH}_{3} \mathrm{OH}(-91 \mathrm{~kJ} / \mathrm{mol}) \\
& \mathrm{CO}_{2}+3 \mathrm{H}_{2} \rightarrow \mathrm{CH}_{3} \mathrm{OH}+\mathrm{H}_{2} \mathrm{O}(-50 \mathrm{~kJ} / \mathrm{mol})
\end{aligned}
$$

A significant amount of heat is released during the synthesis. The reactors are either isothermal (pressurecontrolled boiling water reactors) or adiabatic (several reactors with intermediate cooling). The catalysts are based on $\mathrm{Zn}, \mathrm{Cu}, \mathrm{Al}$ and/or $\mathrm{Cr}$ components and offer very high selectivities $>99.9 \%$, which ensures high yields and low amounts of by-products. Following synthesis and partial recycling for increased conversion rates, the product is purified via distillation and cooling in three columns: (1) separation in a gas-liquid separator; (2) separation of dissolved gases in a topping column; and (3) separation of water and other liquid by-products. The key by-product is ethanol, which is removed along with the produced water (Røngaard Clausen, 2011).

Methanol can be further refined to, for example, di-methyl ether (DME) or gasoline. These conversion processes are typically connected, as the DME is the first step towards gasoline. While DME $\left(\mathrm{CH}_{3} \mathrm{OCH}_{3}\right)$ can be directly synthesized from $\mathrm{H}_{2}$ and $\mathrm{CO}$, it is traditionally synthesized via methanol dehydration at similar reactor and process conditions:

$$
2 \mathrm{CH}_{3} \mathrm{OH} \rightarrow \mathrm{CH}_{3} \mathrm{OCH}_{3}+\mathrm{H}_{2} \mathrm{O}(-23 \mathrm{~kJ} / \mathrm{mol})
$$

Further processing for gasoline can then feature further dehydration and the co-production of hydrocarbons (e.g. $\mathrm{C}_{2}-\mathrm{C}_{5}$ gases, paraffins, aromats) and water (Basu, 2013).

The overall process from product gas to methanol can be broken down into subprocesses as shown in Fig. 5 . Tar represents the most significant challenge for gasification systems. Besides tar and inorganic components (that are discussed in the next section), the synthesis plant should be coupled to a gasifier that can ensure optimal conversion from biomass to methanol: high cold gas efficiency, no/negligible levels of methane and inert nitrogen and a high hydrogen content. 


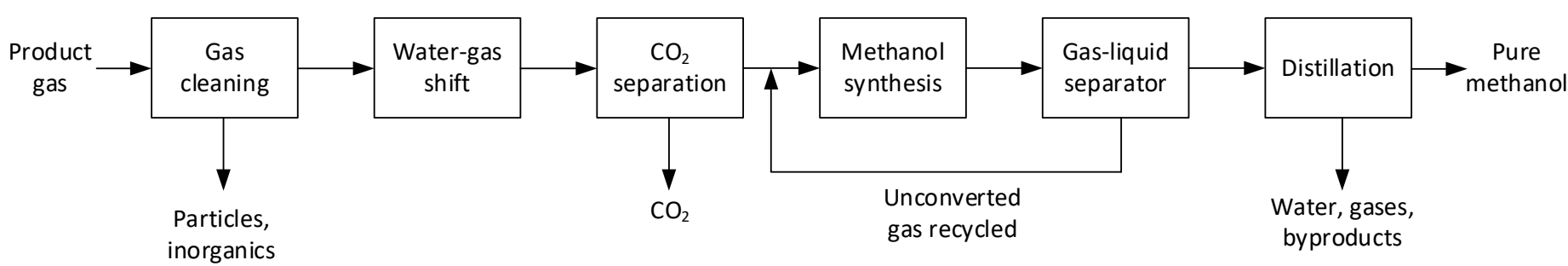

Figure 5. Typical flow diagram for methanol synthesis from product gas. The compression step can be at gasifier (fuel inlet) or prior to gas cleaning.

Particles and sulphur are the main issues in focus during the initial cleaning of the product gas, but also other inorganic compounds are of interest as the downstream equipment is extremely sensitive to impurities. Desulphurizing the gas is crucial and a well-known process because natural gas typically carries significant amounts of sulphur. The most used gas cleaning method is the commercial Rectisol process (Gatti et al., 2014; Sun and Smith, 2013). It is a convenient method as it utilizes pressurized cooled methanol (around $-40^{\circ} \mathrm{C}$ ) as a solvent for a range of impurities including $\mathrm{CO}_{2}, \mathrm{H}_{2} \mathrm{~S}, \mathrm{COS}, \mathrm{HCl}$ and $\mathrm{NH}_{3}$. The primary downsides of Rectisol are that it is mostly applicable to large-scale plants and that it requires a refrigeration plant consuming electricity. Other commercial gas cleaning processes for sulphur and/or $\mathrm{CO}_{2}$ include Selexol and Purisol (Kapetaki et al., 2015; Vitasari et al., 2011).

In order to ensure a high yield of methanol in the synthesis reactor, the gas composition typically needs to be adjusted for $\mathrm{H}_{2}, \mathrm{CO}$ and $\mathrm{CO}_{2}$ content. One way to define the optimal relationship between these components is given on a molar basis in Eq. 5. Here, the value of $M$ should be at least 2 and preferably higher. The catalytic water-gas-shift reactor is applied for this very purpose at $200-500^{\circ} \mathrm{C}$. This reactor might be placed ahead of the primary gas cleaning if a sulphur-tolerant catalyst is chosen and/or if the cleaning step should also remove the produced $\mathrm{CO}_{2}$.

$M=\frac{\mathrm{H}_{2}-\mathrm{CO}_{2}}{\mathrm{CO}+\mathrm{CO}_{2}}$

The synthesis is done in one or more catalytic reactors at $240-400^{\circ} \mathrm{C}$ and $50-300$ bar (below 100 bar is typical) depending on the process (reactor, gas composition, pressure). An analysis of the process conditions is shown with the CO conversion rate in Fig. 6 for methanol and DME. The highest yield of methanol at equilibrium is at lower temperatures, but a higher value is often chosen to ensure a high reaction rate. High pressures are favourable as both equilibrium and the reactions are increased. 


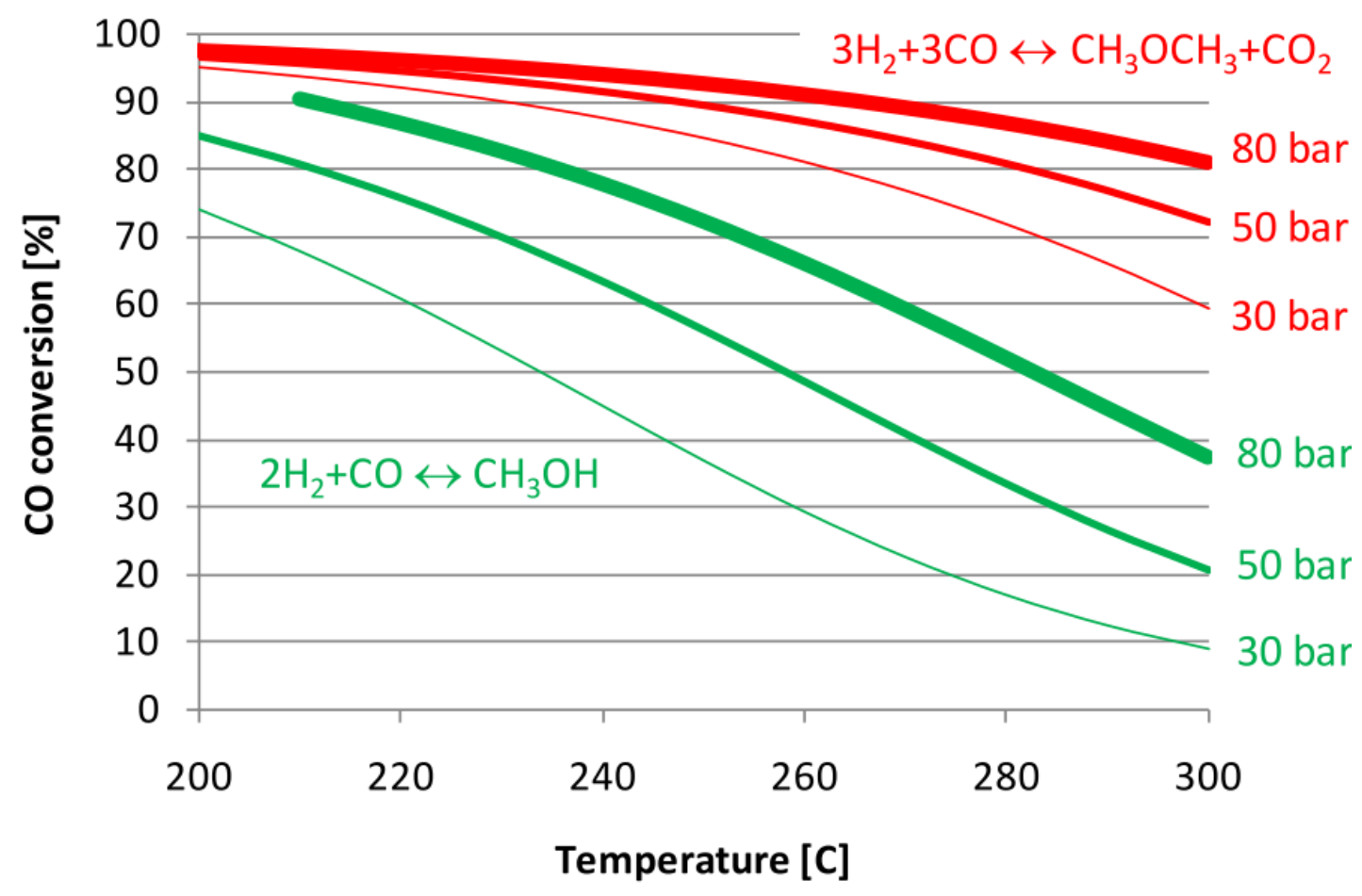

Figure 6. Equilibrium $\mathrm{CO}$ conversion as a function of the reactor temperature and the reactor pressure. Used with permission from Røngaard Clausen (2011). Methanol and DME $\left(\mathrm{CH}_{3} \mathrm{OCH}_{3}\right)$ curves are calculated via optimal gas compositions with $\mathrm{H}_{2} / \mathrm{CO}$ ratios of 2 and 1 , respectively.

\subsection{Synthesis of synthetic natural gas (SNG)}

Synthetic natural gas ( $\mathrm{SNG}$ or biomethane, $\mathrm{CH}_{4}$ ) has gathered, like methanol, significant interest in the framework of the energy system transition, as it already has large infrastructure in place. SNG is nearly identical to traditional natural gas, as it possesses identical properties, but has a $\mathrm{CO}_{2}$-neutral footprint as it originates from biomass. SNG production is therefore expected to be relatively feasible, as the existing infrastructure can be largely kept. This also means that the requirements for quality/purity of the SNG are closely tied to those of the existing natural gas grid that acts as the physical gateway to the market. While the coal-to-SNG process is fully commercial, biomass-to-SNG is at pilot or early commercial demonstration (Rönsch et al., 2016), mainly because of a lack of economic incentive more than technical challenges. The biomass-to-SNG efficiency is relatively high and models show values in the range of 55-65\% (Rönsch et al., 2016; van der Meijden et al., 2010).

A process flow diagram for SNG synthesis is shown in Fig. 7. Synthesizing methane requires a higher hydrogen:carbon ratio, compared with methanol synthesis, as it is evident from the key reactions:

$\mathrm{CO}+3 \mathrm{H}_{2} \rightarrow \mathrm{CH}_{4}+\mathrm{H}_{2} \mathrm{O}(-206 \mathrm{~kJ} / \mathrm{mol})$

$\mathrm{CO}_{2}+4 \mathrm{H}_{2} \rightarrow \mathrm{CH}_{4}+2 \mathrm{H}_{2} \mathrm{O}(-165 \mathrm{~kJ} / \mathrm{mol})$ 


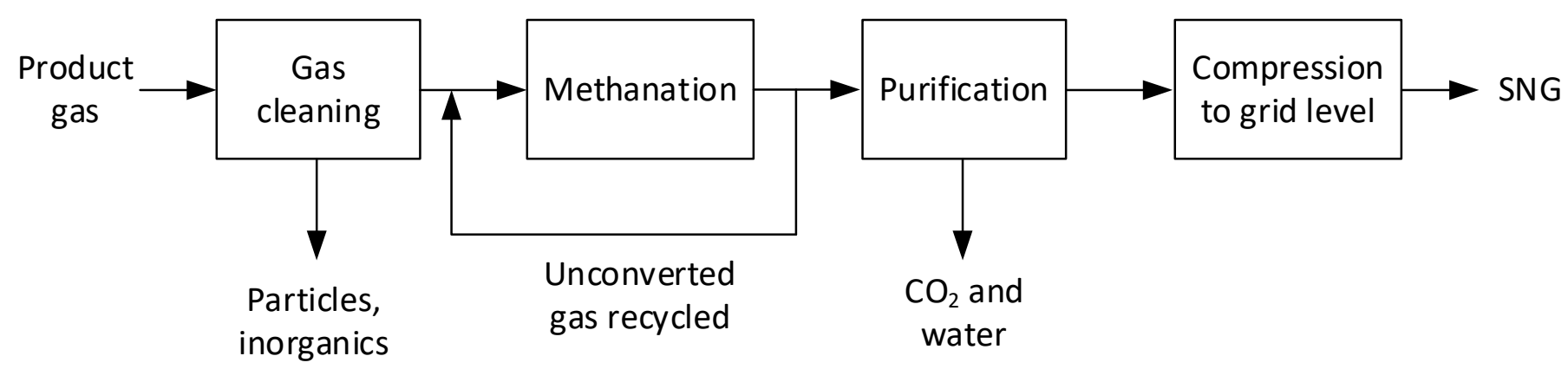

Figure 7. Typical flow diagram for SNG synthesis from product gas. Compression prior to the methanation can take place at the gasifier (fuel inlet) or at either end of the gas cleaning.

The process conditions are typically around $250-700^{\circ} \mathrm{C}$ and $10-30$ bar for SNG synthesis. The reactions in Eq. 6 and Eq. 7 are favoured at lower temperature and higher pressures as seen in Di Felice and Micheli (Di Felice and Micheli, 2015). The temperature level is closely linked to the reactor choice, which can either be a water-cooled isothermal fluid bed or an adiabatic fixed/fluid bed. Adiabatic reactors are the most common ones, and three reactors or more, with intermediate cooling, are typically required to ensure a high conversion. The excess heat can be used to, for example, power a steam cycle for power generation. The commercial reactors are predominantly nickel-based and offer both low costs and high activity. They can also facilitate water-gas-shift reactions internally.

Methanation is a very exothermic process that has a heat release in the range of $20 \%$ of the input LHV of the reactants or $\approx 2 \mathrm{~kW} / \mathrm{Nm}^{3}{ }_{\mathrm{CH} 4}(\approx 2.6$ times more than methanol on a molar basis; Rönsch et al., 2016). Therefore, heat management is essential in SNG plants and careful component control as well as plant integration are needed to ensure high efficiencies. After synthesis, a part of the gas is recycled, and the raw SNG product is purified from $\mathrm{CO}_{2}$ and water dilution. While water is removed via cooling, pressurized gas washes such as the commercial Selexol process are mostly used (Kapetaki et al., 2015; Vitasari et al., 2011). After purification, the SNG is compressed to the local natural gas grid pressure level and directly injected into the grid. 


\section{Carbon balance value of by-products from thermal gasification of biomass}

An overview of common process input and process output (products and by-products) from thermal biomass gasification is provided in Fig. 8.

Output:

Output:

Products: Heat, power, liquid fuels, gaseous fuels, chemicals

By-products/residues/waste: Ashes, chars, filter cake, wastewater/ condensate, sludge, spent materials, exhaust gas

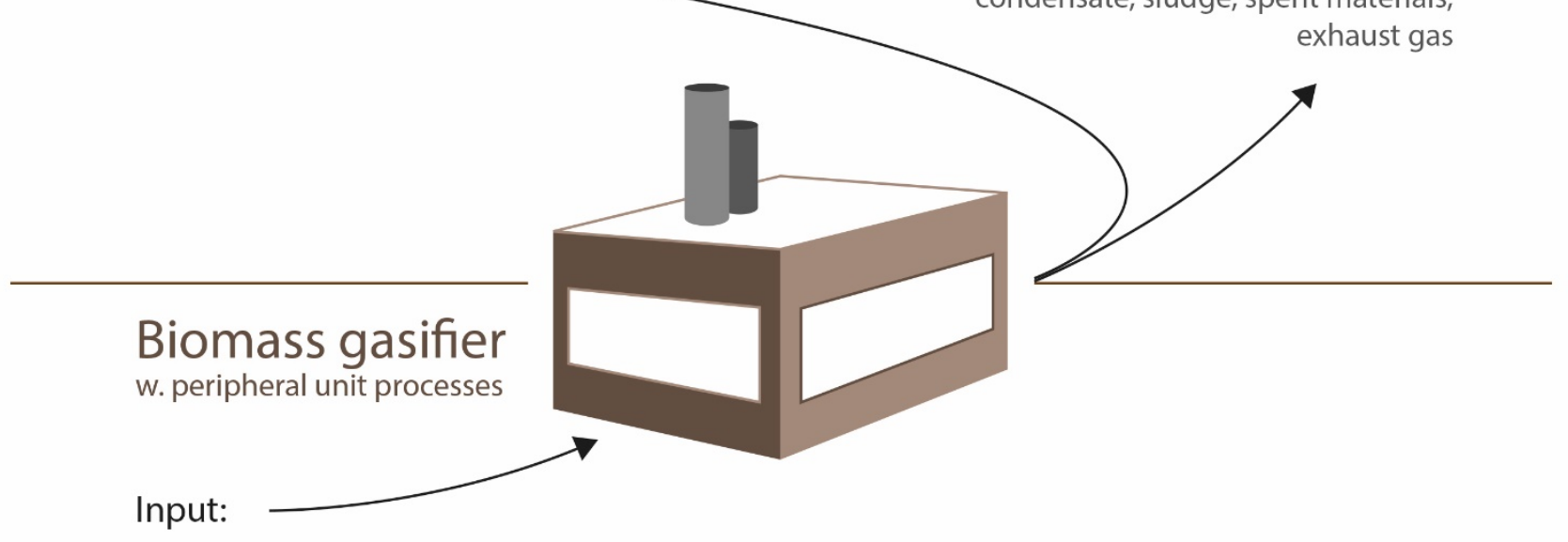

Fuel: Biomass, residues, waste

Gasification agents and reagents: Air, steam/water, oxygen, carbon dioxide, hydrogen

Utilities: Power, water, nitrogen, propane, catalysts, acids, bases, active carbon etc.

Figure 8. Illustration of common input and output from biomass gasification.

The mass and volume fractions of by-products from biomass gasification vary substantially with the type of biomass fuel converted as well as the product portfolio from the specific process.

In general, there are three main routes to achieve carbon-negative energy production from thermal gasification of biomass, and all routes require proper management of by-products. These routes involve production of energy services (heat, power, fuels) combined with one or several of the following by-product management strategies:

- Long-term sequestration of $\mathrm{CO}_{2}$ captured from the off-gases;

- Long-term sequestration of recalcitrant carbon in chars and ashes; and

- Production of marketable non-energy products to substitute equivalent products on the market.

To address the influence of by-products on the carbon balance of the energy production, it is important to consider the complete carbon balance of the energy system:

$C_{\text {balance }}=\frac{\Sigma C O_{2 e q, \text { emited }}-\Sigma C O_{2 e q, \text { stored }}-\Sigma C O_{2 \text { eq, displaced }}-\Sigma C O_{2 \text { eq, captured }}}{\text { Net Energy Services }(N E S) \text { provided }}, N E S>0$ 
$\mathrm{CO}_{2}$ eq, emitted includes emissions from the exhaust as well as from biomass procurement, production of utilities, transportation and so forth. $\mathrm{CO}_{2}$ eq, stored includes long-term sequestration of carbon in the shape of $\mathrm{CO}_{2}$ (CCS) or recalcitrant carbon in char and ash. The temporal scope of the sequestration potential should follow the scope of the global warming potential of the assessed GHGs (IPCC, 2013). $\mathrm{CO}_{2}$ eq, displaced includes the representative carbon intensity on the present market of marketable by-products produced from the system. $\mathrm{CO}_{2}$ eq, captured includes the carbon captured from the atmosphere in the process, primarily via photosynthesis in the biomass growth phase. Net Energy Services provided include the net sum of all energy products provided from the biomass gasification system to society.

All elements are sums $(\Sigma)$. of direct and indirect emissions for all quantified GHGs. All GHGs emitted $\left(\mathrm{CO}_{2}, \mathrm{CH}_{4}, \mathrm{~N}_{2} \mathrm{O}, \mathrm{CFCs}\right.$ and so forth) need to be recalculated into $\mathrm{CO}_{2}$ equivalents using relevant impact factors and aggregated (IPCC, 2013). In addition, carbon-negative energy production requires a negative numerator and a positive denominator on the right-hand side. Systems with a negative Net Energy Service provided are not energy production systems, but may be categorized as energy conversion systems, converting low-quality energy services or carriers to high-quality energy services or carriers.

The potential for carbon-negative energy production from biomass gasification with CCS (long-term storage of $\mathrm{CO}_{2}$ from off-gases) is substantial but struggles with economical and technical feasibility, especially with regard to retrofitting of existing plants. A recent study has indicated that equipping a biofuel production (liquid or gaseous) based on thermal gasification of biomass with CCS would double the climate benefit of the system with an additional cost of around 10\% (Álamo et al., 2018; Hardisty et al., 2011).

Quantity and quality of ashes and chars from biomass gasification vary heavily with the fuel characteristics as well as the process design and operational parameters (Thomsen et al., 2016). In addition, many gasifiers will have more than one ash/char product from the process. This is illustrated in Fig. 9 with an example of a low-temperature biomass gasifier. In this design, there is a potential to extract at least three different ash/char fractions from the process which will all have very different characteristics.

For successful sequestration of carbon via ashes and chars, it is essential that the carbon in the solid residuals is stable in the environment in which it is stored. In addition, the quality of the char and ash has to be high enough for it to be feasible and attractive for the desired application. Usually, char and ash are applied to soil, and it is therefore often the carbon stability in the related terrestrial systems that are relevant for the carbon balance. Only a few studies have been conducted on the long-term stability of gasification biochar, but based on the results it can be expected that gasification biochar is highly stabile in soil systems with sequestration periods longer than a 100 years (common temporal scope for carbon balance assessments) for the majority of the carbon (Hansen et al., 2015, 2016; Shackley et al., 2012).

Many more studies on the stability of carbon in pyrolysis biochar have been conducted with very positive results and expected sequestration periods from hundreds to thousands of years (Bruun et al., 2011; Budai et al., 2013; Cheng et al., 2006; Lehmann et al., 2006; Nguyen et al., 2008). The gasification system benefits from generally higher temperature and longer total retention time of solids in the systems, leading to lower O:C ratios which increase carbon recalcitrance, whereas pyrolysis systems often benefit from higher total carbon recovery in the solid fractions (Bai et al., 2014). 


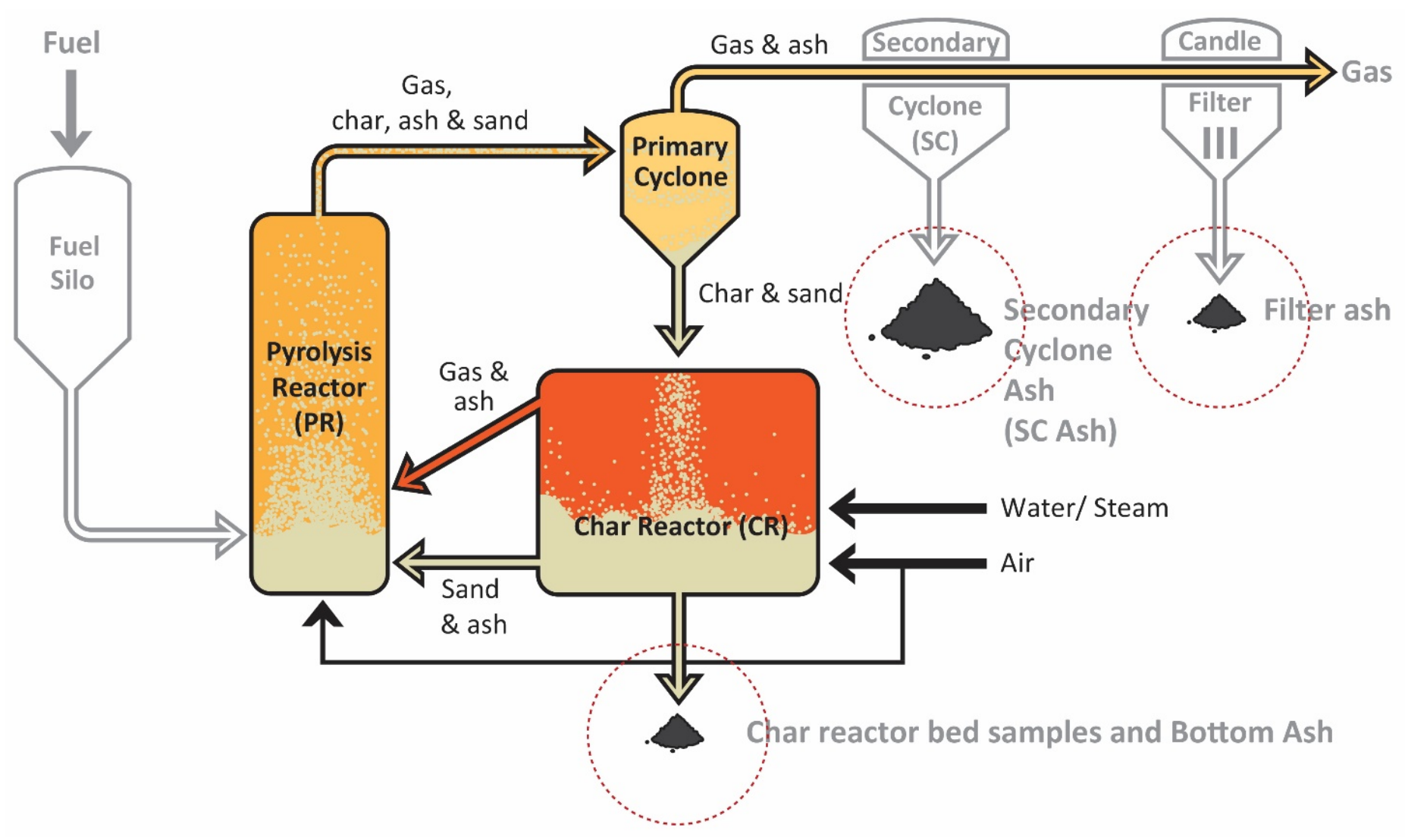

Figure 9. Low-temperature circulating fluidized-bed schematic design and ash/char products. Adapted with permission from Thomsen et al. (2017c).

If the solids are applied in a landscaping effort, then it is also relevant if the use implies environmental risks or pollution. If the char or ash is amended to farm soil, it would often be as a fertilizer or a soil enhancer, and this would require fertilizer value and/or soil enhancement potential in the form of, for example, improvements of soil structure, water-holding capacity, cation exchange capacity and so forth. Soil enhancement effects as well as potential fertilizer value of gasification biochar and ash will vary substantially with the feedstock, design of the gasifier, the operational parameters and the soil system in which it is applied. Gasification of nutrient-rich substances such as straw or sewage sludge may provide ashes or chars with a high fertilizer value of especially potassium and phosphorous, while gasification of wood may provide valuable chars with vast soil enhancer qualities if gasifier design and end-use is properly aligned (Bruun et al., 2014; Hansen et al., 2015, 2016; Kuligowski et al., 2008, 2012; Li et al., 2017; Mackay et al., 2016; Müller-Stöver et al., 2014; Thompson et al., 2016). Two different ashes from thermal gasification of sewage sludge are shown in Fig. 10 to illustrate how different the solid residuals may be even when the fuel substrate is the same. In addition to these two samples, the complete set of solid residuals included cyclone ashes and filter ashes as well (Thomsen et al., 2016). 

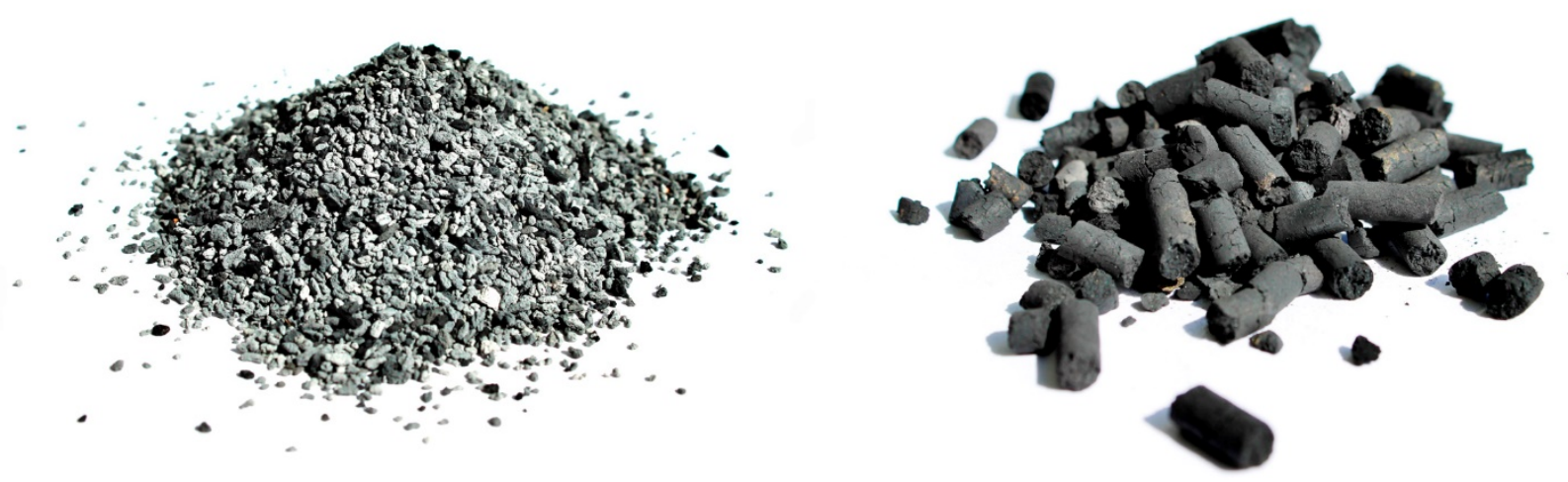

Figure 10. Two different ashes produced from the same sewage sludge substrate by thermal gasification in a low-temperature circulating fluidized-bed gasifier (left) and a two-stage downdraft gasifier (right).

When producing gasification chars or ashes with a nutritional value which is marketable as a fertilizer substrate, then it is relevant to include this value in the carbon balance. This is commonly done in Life Cycle Assessment studies via System Expansion or Avoided Production and gives a reasonable credit to systems with co-production of high-quality by-products (European Commission et al., 2010). In practice, it implies subtraction of emissions from representative production of an equivalent quantity of the replaced product on the market. In addition to fertilizer value, it may also be relevant to include avoided production of other marketable by-products including gas/water filter media, road material, metal procurement, manure treatment, BBQ charcoal, animal feeding, chemical grade pulverized active carbon (Huber, 2017; Rüegsegger and Kast, 2018). 


\section{System integration for polygeneration}

Gasification of biomass can be an important platform for future biorefineries producing various biofuels and biochemicals. If the biorefinery also includes a heat engine or fuel cell for syngas conversion to electricity, it is possible to make a flexible biorefinery that can switch to electricity production when the electricity demand is high. Furthermore, if electricity from renewables, such as wind and solar, is supplied to the biorefinery together with the biomass input, it is possible to enable a full utilization of the biomass carbon. The electricity input can be used for water/steam electrolysis to produce hydrogen for syngas production, and oxygen for the gasifier. If solid oxide cells (SOC) are used for steam electrolysis (SOEC), these cells can also be used as fuel cells (SOFC) for electricity production, when the electricity production from renewables is low. Systems combining gasification and SOCs have been studied in numerous articles for either electricity production (Bang-Møller et al., 2011; Gadsbøll et al., 2017; Omosun et al., 2004; Panopoulos et al., 2006) or fuel production (Bernical et al., 2013; Clausen, 2017), but few studies look at both electricity and fuel production and investigate the potential of such polygeneration systems or flexible biorefineries (Fig. 11).

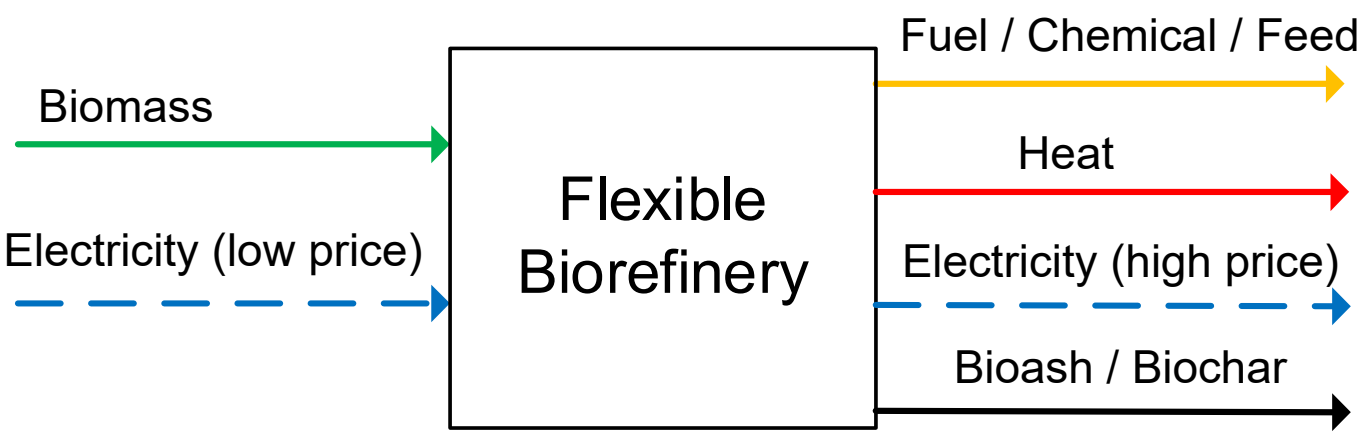

Figure 11. Diagram of a biorefinery based on thermal gasification integrated with water/steam electrolysis.

\subsection{Flexible biorefineries}

A flexible biorefinery integrating gasification and SOC can operate in at least three to four different modes, which makes it possible to adjust the electricity input or output to the current electricity price on the grid. The operating modes differ in gasifier operation and the SOC operation - for example, if the SOC operates in SOEC mode, the gasifier could be oxygen-blown, but if the SOC operates in SOFC mode, there is no oxygen production, and the gasifier could instead be air-blown. When the gasifier is air-blown, once-through synthesis of liquid fuels or chemicals could be feasible (Clausen et al., 2011), but production of gaseous fuels would be infeasible due to nitrogen dilution. An overview of operating modes can be seen in Table 4 and Fig. 12. Figure 12 is very simplified, and real systems would include syngas cleaning and conditioning before fuel synthesis. If, for example, methane is produced, $\mathrm{CO}_{2}$ removal would be necessary in Fig. 12b, otherwise the produced methane would have a large $\mathrm{CO}_{2}$ content. If a liquid fuel is produced, $\mathrm{CO}_{2}$ removal would most likely be used in both Fig. 12a and $\mathrm{b}$ to lower the synthesis reactor size and reduce the syngas loss by the synthesis loop purge (Clausen, 2015). 
Table 4. Overview of operating modes for a biorefinery based on biomass gasification and solid oxide cells

\begin{tabular}{|l|l|l|l|l|}
\hline $\begin{array}{l}\text { Operating } \\
\text { mode }\end{array}$ & Gasifier & SOC & $\begin{array}{l}\text { Synthesis of } \\
\text { biofuel* }\end{array}$ & $\begin{array}{l}\text { Electricity } \\
\text { consumption } \\
(-) / \text { production }(+)\end{array}$ \\
\hline $\begin{array}{l}\text { Electricity } \\
\text { storage mode }\end{array}$ & $\begin{array}{l}\text { Oxygen- } \\
\text { blown }\end{array}$ & $\begin{array}{l}\text { SOEC mode. Covers } \\
\text { hydrogen demand }\end{array}$ & +++ & -- \\
\hline $\begin{array}{l}\text { Oxygen } \\
\text { demand mode }\end{array}$ & $\begin{array}{l}\text { Oxygen- } \\
\text { blown }\end{array}$ & $\begin{array}{l}\text { SOEC mode. } \\
\text { Covers oxygen demand }\end{array}$ & ++ & -- \\
\hline $\begin{array}{l}\text { Once-through } \\
\text { synthesis mode }\end{array}$ & Air-blown & $\begin{array}{l}\text { SOFC mode. Unconverted gas } \\
\text { from synthesis to SOFC }\end{array}$ & $\begin{array}{l}+ \\
\text { Only synthesis of } \\
\text { liquid fuel }\end{array}$ & + \\
\hline $\begin{array}{l}\text { Electricity } \\
\text { production } \\
\text { mode }\end{array}$ & Air-blown & $\begin{array}{l}\text { SOFC mode. Syngas directly } \\
\text { to SOFC }\end{array}$ & ++ \\
\hline
\end{tabular}

* ' + ' is used to denote the biofuel production, ' +++ ' is the maximum biofuel production.

a)

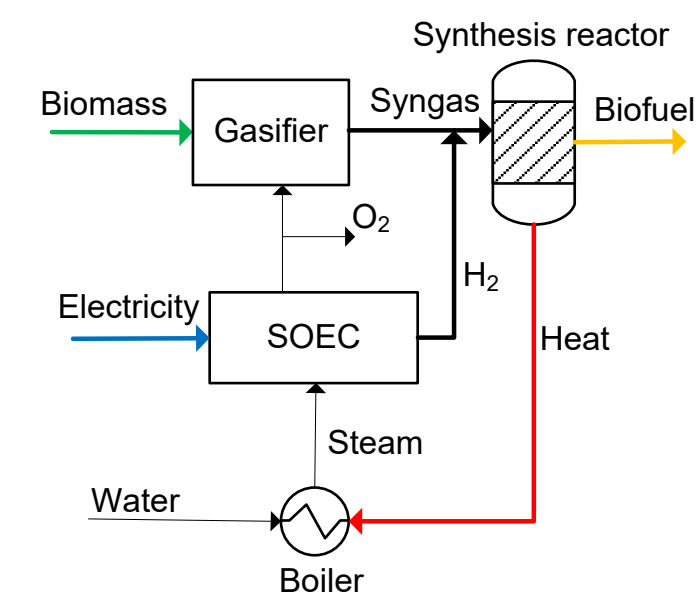

c)

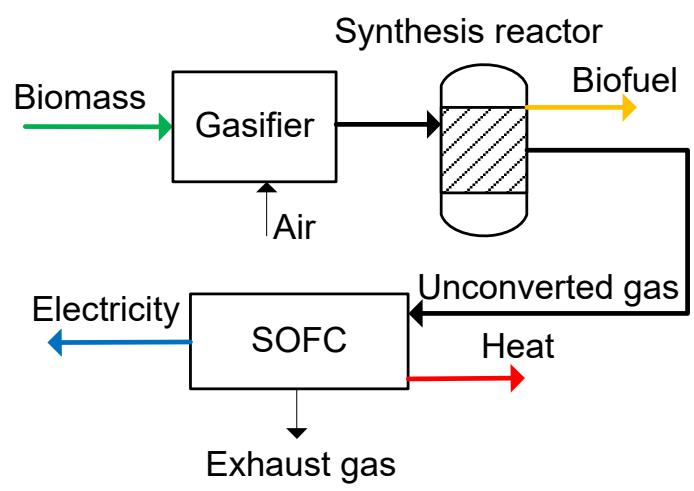

b)

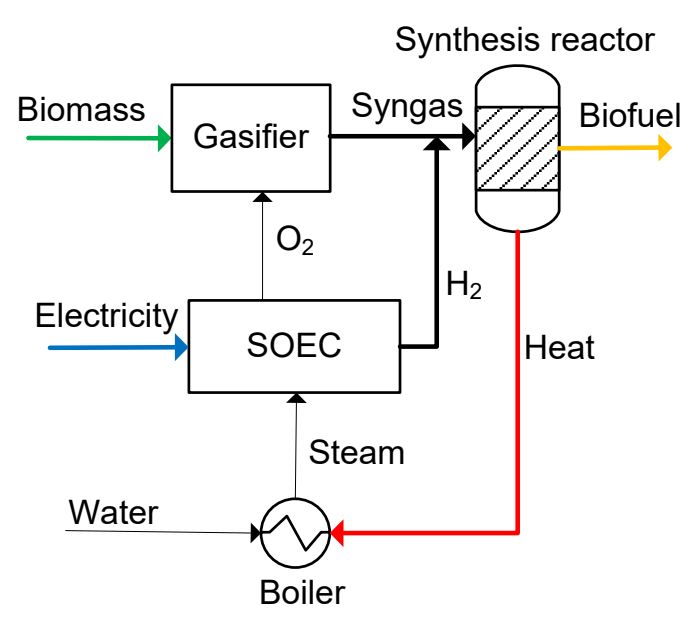

d)

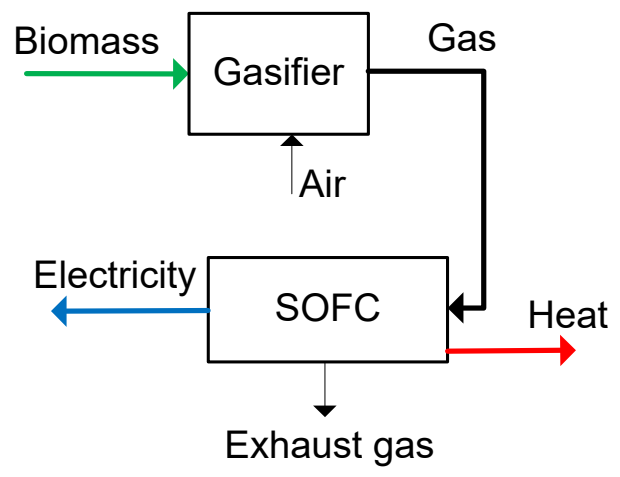

Figure 12. Simplified flowsheets of a biorefinery based on biomass gasification and solid oxide cells (SOC) operating in various modes: (a) electricity storage mode, (b) oxygen demand mode, (c) once-through synthesis mode, (d) electricity production mode. Note that the gasifier produces bioash/biochar, although not shown on the figures. 
Most of the operating modes shown in Fig. 12 have been studied previously as single-mode systems, for example, the system in Fig. 12d has been widely studied by thermodynamic modelling (Bang-Møller et al., 2011; Omosun et al., 2004; Panopoulos et al., 2006) and has also been proven experimentally (Gadsbøll et al., 2017). The experimental tests have proven the feasibility of combining gasification and SOFCs and have demonstrated biomass to electricity efficiencies of up to $43 \%$, with a potential of increasing this to $62 \%$ when integrating a gas turbine (Gadsbøll et al., 2017). The system in Fig. 12a has so far only been studied theoretically by thermodynamic modelling (Bernical et al., 2013; Clausen, 2017). These analyses find biomass-to-biofuel efficiencies of 59-70\%, depending mainly on the gasifier type and the biofuel produced. Highest efficiency is found for the system producing methane (Clausen, 2017), but this efficiency could potentially be increased to $\sim 75 \%$ if methanol or DME is produced instead, as synthesis of these fuels is less exothermic than methane synthesis (Clausen, 2017).

\subsection{Pressurization and internal methanation in solid oxide cells (SOC)}

Pressurization of both gasifier and SOC could be highly feasible for large-scale systems, and would reduce the syngas and would reduce the consumption of power for syngas compression. Pressurized gasification is typically assumed for large-scale systems (Clausen, 2015; Larson et al., 2009) and is commercially used by coal gasifiers, but pressurized SOC operation is rarely assumed, and only few pressurized SOC experiments have been performed (Jensen et al., 2016, 2017).

If the biofuel produced is methane, there is an additional benefit of SOC pressurization, as it is possible to have internal methanation inside a state-of-the-art SOC if carbonaceous gasses are supplied to the SOC (Butera et al., 2019; Jensen et al., 2015, 2017). This can be achieved by sending humidified syngas to the SOC (Fig. 13). As the methanation synthesis reaction is highly exothermic, it is a perfect match for the endothermic $\mathrm{H}_{2} \mathrm{O}$ and $\mathrm{CO}_{2}$ electrolysis reactions. Thermodynamic system modelling predicts that approximately $50 \%$ of the methane is formed in the SOC; this significantly increases the output-to-input efficiency of the overall system, as heat released by the methanation reaction inside the SOC can replace a part of the electricity input to the SOEC. Another benefit of such a system is that a change in operating mode from electricity storage (Fig. 13) to electricity production (Fig. 12d) would be simpler, as the input to the SOC is always syngas, whereas the SOC changed input from steam to syngas in Fig. 12.

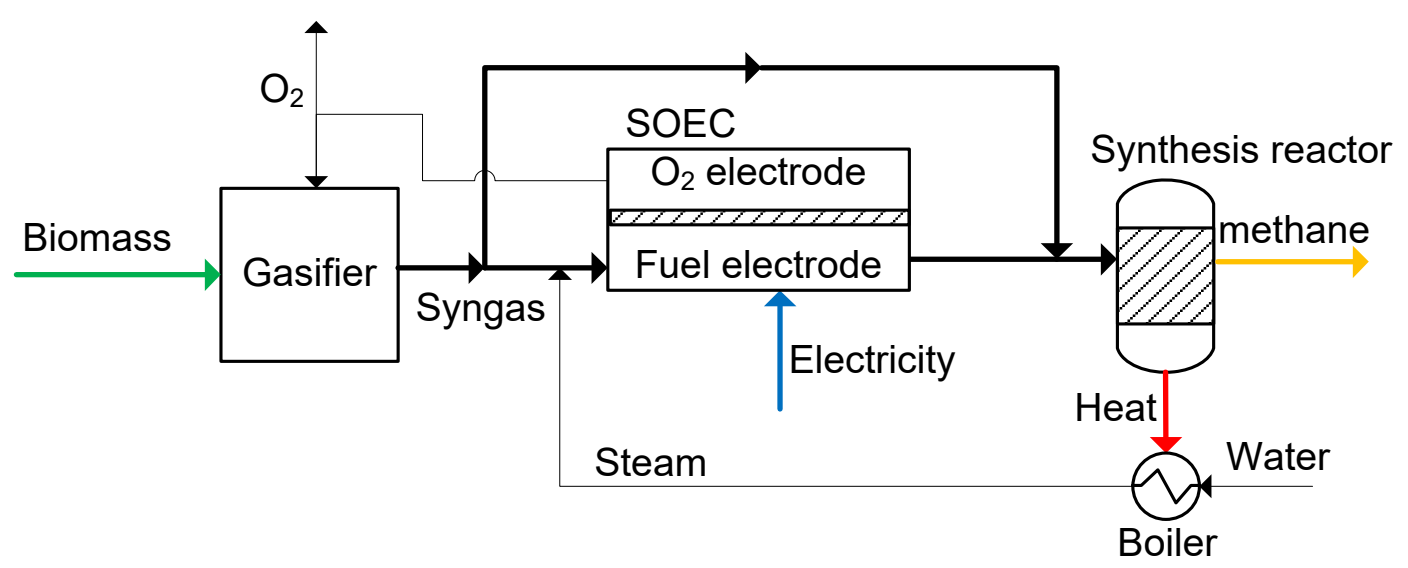

Figure 13. Simplified flowsheet of a methane-producing system based on pressurized gasification and pressurized SOC with internal methanation. Note: part of the syngas bypasses the SOEC to allow (1) a high H/C ratio in the SOEC, thereby avoiding equilibrium carbon formation (Butera et al., 2019), and (2) having the optimal ratio between $\mathrm{H}_{2}, \mathrm{CO}$ and $\mathrm{CO}_{2}$ for methane synthesis before the synthesis reactor (Butera et al., 2019). 
If other biofuels than methane are produced, it would still be possible to feed a pressurized SOEC with syngas, but it requires the use of SOECs without nickel in the fuel electrode, as nickel catalyses methane synthesis. A promising candidate is electrodes based on doped-ceria (Graves et al., 2016). Another option would be to have both gasifier and SOEC operate at atmospheric pressure; in this way, a state-of-the-art nickel containing SOEC could be used. At atmospheric pressure, thermodynamics will limit the methane production if sufficient high-temperature and high-oxygen content at the SOEC outlet is used.

\section{Conclusion}

Biomass gasification is a versatile and flexible process that can provide substantial contributions to modern biorefinery concepts and energy systems. The purpose of this chapter has been to give an introduction to the current state-of-the-art, recent research, development efforts and classic challenges related to integration and operation of this technology. The main parameters affecting the syngas production and composition such as gasification technologies, feedstock characteristics and operating gasification conditions have been presented. The importance of gas cleaning and conditioning depending on the downstream processes has also been highlighted.

The majority of the existing biomass gasification systems are small-scale wood gasifiers built for CHP production in integrated gas engines with power production capacities averaging around $80 \mathrm{~kW}$ power per unit. However, ongoing research focusses on using the product gas for Fischer-Tropsch synthesis to produce hydrocarbons, methanol synthesis or production of SNG. Research is managing to solve and overcome the technical challenges of these downstream processes; however, there is still a lack of economic incentive that is preventing these technologies from being commercially available.

In the optics of a circular economy, gasification processes' products and by-products should find use in order to minimize the waste streams and increase product and process value. Particularly, chars and ashes offer several options for being recycled in an efficient and sustainable way as active carbon or for soil amendment, remediation and carbon sequestration.

In the scope of carbon-negative bioenergy production, thermal gasification of biogenic material has substantial beneficial potentials. The potentials arise from a combination of high thermal efficiency, high fuel and product flexibility, value of by-products, possible integration with bio-CCS and SOCs and direct carbon sequestration by soil amendment of chars and ashes. In the future, this potential is expected to increase further as new concepts and solutions such as process integration schemes, combinations of different technologies and new polygeneration strategies will contribute to maximize product yield and value, increase the overall process efficiency, improve the economic viability and overcome the operational challenges that the technology is currently facing.

\section{Where to look for further information}

The first and second edition of the "Handbook of Biomass Gasification" published by the BTG Biomass Technology Group BV in the Netherlands provides a good introduction to the subject for non-specialists as well as reviews of the current state of technology and a description of the latest success stories.

The IEA Bioenergy Task 33 "Gasification of Biomass and Waste" is a working group of international experts with the aim to promote the commercialization of efficient, economical and environmentally preferable thermal biomass gasification processes. On their website, it is possible to find several publications and reports regarding biomass gasification as well as a list of the most relevant conferences and workshops in the field. 


\section{References}

Abdoulmoumine, N., Adhikari, S., Kulkarni, A., Chattanathan, S. (2015) A review on biomass gasification syngas cleanup. Applied Energy 155: 294-307. DOI: 10.1016/J.APENERGY.2015.05.095.

Ahrenfeldt, J., Henriksen, U.B., Jensen, T.K., Gøbel, B., Wiese, L., Kather, A., Egsgaard, H.(2006) Validation of a continuous Combined Heat and Power (CHP) operation of a two-stage biomass gasifier. Energy \& Fuels 20(6): 2672-80. DOI: 10.1021/ef0503616.

Ahrenfeldt, J., Egsgaard, H., Stelte, W., Thomsen, T.P., Henriksen, U.B. (2013a) The influence of partial oxidation mechanisms on tar destruction in TwoStage biomass gasification. Fuel 112. DOI: 10.1016/j.fuel.2012.09.048.

Ahrenfeldt, J., Thomsen, T.P., Henriksen, U., Clausen, L.R. (2013b) Biomass gasification cogeneration - A review of state of the art technology and near future perspectives. Applied Thermal Engineering 50(2): 1407-17. DOI: 10.1016/J.APPLTHERMALENG.2011.12.040.

Álamo, G. del, Sandquist, J., Vreugdenhil, B.J., Aranda Almansa, G., Carbo, M. (2018) Implementation of Bio-CCS in biofuels production - IEA Bioenergy Task 33 special project.

Asadullah, M. (2014a) Barriers of commercial power generation using biomass gasification gas: A review. Renewable and Sustainable Energy Reviews 29: 201-15. DOI: 10.1016/j.rser.2013.08.074.

Asadullah, M. (2014b) Biomass gasification gas cleaning for downstream applications: A comparative critical review. Renewable and Sustainable Energy Reviews 40: 118-32. DOI: 10.1016/J.RSER.2014.07.132.

Bai, M., Wilske, B., Buegger, F., Bruun, E.W., Bach, M., Frede, H.G., Breuer, L. (2014) Biodegradation measurements confirm the predictive value of the O:C-ratio for biochar recalcitrance. Journal of Plant Nutrition and Soil Science 177: 633-7. DOI: 10.1002/jpln.201300412.

Baliban, R.C., Elia, J.A. and Floudas, C.A. (2013) Novel natural gas to liquids processes: Process synthesis and global optimization strategies. American Institute of Chemical Engineers Journal 59(2): 505-31. DOI: 10.1002/aic.13996.

Bang-Møller, C., Rokni, M. and Elmegaard, B. (2011) Exergy analysis and optimization of a biomass gasification, solid oxide fuel cell and micro gas turbine hybrid system. Energy 36(8): 4740-52. DOI: 10.1016/j.energy.2011.05.005.

Basu, P. (2013) Biomass Gasification, Pyrolysis and Torrefraction. Second Edition. Dalhouse University: Elsevier Inc.

Basu, P. (2018) Design of biomass gasifiers. In: Biomass Gasification, Pyrolysis and Torrefaction. 3rd ed. Academic Press.

Behera, B.K. and Varma, A. (2019) Bioenergy for Sustainability and Security. Springer International Publishing.

Bergthorson, J.M. and Thomson, M.J. (2015) A review of the combustion and emissions properties of advanced transportation biofuels and their impact on existing and future engines. Renewable and Sustainable Energy Reviews 42: 1393-417. DOI: 10.1016/j.rser.2014.10.034.

Bernical, Q., Joulia, X., Noirot-Le Borgne, I., Floquet, P., Baurens, P., Boissonnet, G. (2013) Sustainability assessment of an integrated high temperature steam electrolysis-enhanced biomass to liquid fuel process. Industrial \& Engineering Chemistry Research 52(22): 7189-95. DOI: 10.1021/ie302490y.

Böcker-Riese, B. and Bräkow, D. (2017) Status quo from Biomass gasification CHP-plant systems in the FEE - Society for the promotion of renewable energies. In: Task33 Workshop. Small scale gasification for CHP 02.-04. May 2017, Innsbruck, Berlin, 2017. FEE - Society for the Promotion of Renewable Energies. 
Boerrigter, H., Slort, D.J., Bodenstaff, H., Den Uil, H., Van Ree, R., Veringa, H.J. (2004) Gas Cleaning for Integrated Biomass Gasification (BG) and Fischer-Tropsch (FT) Systems Experimental Demonstration of Two BG-FT Systems ("Proof-of-Principle"). Report ECN-C-04-056.

Brandin, J., Tunér, M. and Odenbrand, I. (2011) Swedish Energy Agency Report Small Scale Gasification: Gas Engine CHP for Biofuels. Växjö/Lund.

Bruun, E.W., Hauggaard-Nielsen, H., Ibrahim, N., Egsgaard, H., Ambus, P., Jensen, P.A., Dam-Johansen, K. (2011) Influence of fast pyrolysis temperature on biochar labile fraction and short-term carbon loss in a loamy soil. Biomass and Bioenergy 35(3): 1182-9. DOI: 10.1016/j.biombioe.2010.12.008.

Bruun, E.W., Petersen, C.T., Hansen, E., Holm, J.K., Hauggaard-Nielsen, H. (2014) Biochar amendment to coarse sandy subsoil improves root growth and increases water retention. Soil Use and Management 30(1): 109-18. DOI: 10.1111/sum.12102.

Budai, A., Zimmerman, A., Cowie, A., Webber, J.B.W., Singh, B.P., Glaser, B., Masiello, C.A., Andersson, D., Shields, F., Lehmann, J., Camps Arbestain, M., Williams, M., Sohi, S., Joseph, S. (2013) Biochar Carbon Stability Test Method: An Assessment of Methods to Determine Biochar Carbon Stability. J. Lehmann.

Butera, G., Jensen, S.H. and Clausen, L.R. (2019) A novel system for large-scale storage of electricity as synthetic natural gas using reversible pressurized solid oxide cells. Energy 166: 738-54. DOI: 10.1016/j.energy.2018.10.079.

Cheng, C.-H., Lehmann, J., Thies, J.E., Burton, S.D., Engelhard, M.H. (2006) Oxidation of black carbon by biotic and abiotic processes. Organic Geochemistry 37(11): 1477-88. DOI: 10.1016/j.orggeochem.2006.06.022.

Clausen, L.R. (2015) Maximizing biofuel production in a thermochemical biorefinery by adding electrolytic hydrogen and by integrating torrefaction with entrained flow gasification. Energy 85: 94-104. DOI: 10.1016/j.energy.2015.03.089.

Clausen, L.R. (2017) Energy efficient thermochemical conversion of very wet biomass to biofuels by integration of steam drying, steam electrolysis and gasification. Energy 125. DOI: 10.1016/j.energy.2017.02.132.

Clausen, L.R., Elmegaard, B., Ahrenfeldt, J., Henriksen, U.B. (2011) Thermodynamic analysis of small-scale dimethyl ether (DME) and methanol plants based on the efficient two-stage gasifier. Energy 36(10): 5805-14. DOI: 10.1016/j.energy.2011.08.047.

Dalena, F., Senatore, A., Marino, A., Gordano, A., Basile, M., Basile, A. (2018) Chapter 1 - Methanol production and applications: an overview. Methanol - Science and Engineering 3-28. DOI: 10.1360/zd2013-43-6-1064.

Danish Technological Institute (2011) GreenSynFuels - Economical and Technological Statement Regarding Integration and Storage of Renewable Energy in the Energy Sector by Production of Green Synthetic Fuels for Utilization in Fuel Cells. Final Project Report, March 2011. EUDP project journal number: 64010-0011. Report Editor: Danish Technological Institute

Di Felice, L. and Micheli, F. (2015) From biomass to SNG. In Process Intensification for Sustainable Energy Conversion, pp. 243-66. DOI: 10.1002/9781118449394.ch8.

E4tech (2009) Review of Technologies for Gasification of Biomass and Wastes - Final Report. NNFCC Project 09/008.

Energistyrelsen and Energinet.dk (2012) Technology Data For Energy Plants. Copenhagen.

European Commission, Joint Research Centre and Institute for Environment and Sustainability (2010) International Reference Life Cycle Data System (ILCD) Handbook - General Guide for Life Cycle 
Assessment - Detailed Guidance. EUR 24708 EN. Luxembourg: Publications Office of the European Union. DOI: $10.2788 / 38479$.

Fechete, I. and Vedrine, J.C. (2017) Nanotechnology in Catalysis: Applications in the Chemical Industry, Energy Development, and Environment Protection. First Edition. Sels B and Voorde M Van De (eds). WILEY-VCH Verlag GmbH \& Co. KGaA.

FORCE Technology (n.d.) Harbooere District Heating Plant, Denmark.

Gadsbøll, R.Ø. (2018) Biomass Gasification Polygeneration - Designing and Operating TW-Stage Systems Coupled with Solid Oxide Cell Technology. Technical University of Denmark.

Gadsbøll, R.Ø., Thomsen, J., Bang-Møller, C., Ahrenfeldt, J., Henriksen, U.B. (2017) Solid oxide fuel cells powered by biomass gasification for high efficiency power generation. Energy 131: 198-206. DOI: 10.1016/j.energy.2017.05.044.

Galadima, A. and Muraza, O. (2015) Hydroisomerization of sustainable feedstock in biomass-to-fuel conversion: A critical review. International Journal of Energy Research 39: 741-59. DOI: 10.1002/er.

Gao, Y.N., Liu, S., Zhao, Z., Tao, H.C., Sun, Z.Y. (2018) Heterogeneous catalysis of CO2 hydrogenation to C2+products. Wuli Huaxue Xuebao/ Acta Physico - Chimica Sinica 34(8): 858-72. DOI: 10.3866/PKU.WHXB201802061.

Gatti, M., Martelli, E., Maréchal, F., Consonni, S. (2014) Multi-objective optimization of a Rectisol ${ }^{\circledR}$ process. In: 24th European Symposium on Computer Aided Chemical Engineering, Budapest, Hungary, pp. 1249-54. DOI: 10.1016/B978-0-444-63455-9.50043-X.

Graves, C., Martinez, L. and Sudireddy, B.R. (2016) High performance Nano-Ceria electrodes for solid oxide cells. ECS Transactions 72(7): 183-92. DOI: 10.1149/07207.0183ecst.

Hansen, V., Müller-Stöver, D., Ahrenfeldt, J., Holm, J.K., Henriksen, U.B., Hauggaard-Nielsen, H. (2015) Gasification biochar as a valuable by-product for carbon sequestration and soil amendment. Biomass and Bioenergy 72: 300-08.

Hansen, V., Müller-Stöver, D., Munkholm, L.J., Peltre, C., Haugaard-Nielsen, H., Jensen, L.S. (2016) The effect of straw and wood gasification biochar on carbon sequestration, selected soil fertility indicators and functional groups in soil: An incubation study. Geoderma 269: 99-107. DOI: 10.1016/j.geoderma.2016.01.033.

Hardisty, P.E., Sivapalan, M. and Brooks, P. (2011) The environmental and economic sustainability of carbon capture and storage. International Journal of Environmental Research and Public Health 8(5): 1460-77. DOI: 10.3390/ijerph8051460.

Hasler, P. and Nussbaumer, T. (1999) Gas cleaning for IC engine applications from fixed bed biomass gasification. Biomass and Bioenergy 16(6): 385-95. DOI: 10.1016/S0961-9534(99)00018-5.

Heeb, R. (2010) Up-date on the Harboøre Technology May 2010 IDA Energi, Status af Danske aktiviteter (May).

Henriksen, U., Ahrenfeldt, J., Jensen, T.K., Gøbel, B., Bentzen, J.D., Hindsgaul, C., Sørensen, L.H. (2006) The design, construction and operation of a $75 \mathrm{~kW}$ two-stage gasifier. Energy 31(10-11): 1542-53. DOI: $10.1016 /$ j.energy.2005.05.031.

Heyne, S., Liliedahl, T. and Marklund, M. (2013) Biomass gasification - A synthesis of technical barriers and current research issues for deployment at large scale. Report No 2013:5, f3 The Swedish Knowledge Centre for Renewable Transportation Fuels and Foundation, Sweden. Available at: www.f3centre.se (April 2013). DOI: 10.13140/RG.2.1.2593.8406.

Hrbek, J. (2016) Status Report on Thermal Biomass Gasification in Countries Participating in IEA Bioenergy Task 33. Vienna. 
Huber, M. (2017) The carbon makes the difference - Decentralized wood power plant with valuable carbon as by-product. In: IEA Bioenergy Task 33 Workshop 'Small scale gasification CHP', Innsbruck, Austria, 2017, p. 23. SynCraft Das Holzkraftwerk \& IEA Task 33.

IPCC (2013) Climate Change 2013: The Physical Science Basis. Contribution of Working Group I to the Fifth Assessment Report of the Intergovernmental Panel on Climate Change. Stocker, T.F., Qin, D., Plattner, G.-K., et al. (eds). Cambridge and New York: Cambridge University Press.

Jensen, S.H., Graves, C., Mogensen, M., et al. (2015) Large-scale electricity storage utilizing reversible solid oxide cells combined with underground storage of $\mathrm{CO}_{2}$ and $\mathrm{CH}_{4}$. Energy Environment Science 8: 24719. DOI: $10.1039 /$ C5EE01485A.

Jensen, S.H., Langnickel, H., Hintzen, N., Chen, M., Hauch, A., Butera, G., Clausen, L.R. (2017) Pressurized reversible operation of a 30-cell solid oxide cell stack using carbonaceous gases. In: European Fuel Cell Technology \& Applications Conference - Piero Lunghi Conference, 2017. ENEA.

Jensen, S.H., Sun, X., Ebbesen, S.D., Chen, M. (2016) Pressurized operation of a planar solid oxide cell stack. Fuel Cells 16(2): 205-18. DOI: 10.1002/fuce.201500180.

Kapetaki, Z., Brandani, P., Brandani, S., Ahn, H. (2015) Process simulation of a dual-stage Selexol process for $95 \%$ carbon capture efficiency at an integrated gasification combined cycle power plant. International Journal of Greenhouse Gas Control (39): 17-26. DOI: 10.1016/j.ijggc.2015.04.015.

Krylova, A.Y. (2014) Products of the Fischer-Tropsch synthesis (a review). Solid Fuel Chemistry 48(1): $22-$ 35. DOI: $10.3103 / \mathrm{S} 0361521914010030$.

Kuligowski, K., Gilkes, R.J., Poulsen, T.G., Yusiharni, B.E. (2012) Ash from the thermal gasification of pig manure-effects on ryegrass yield, element uptake, and soil properties. Soil Research 50(5): 406-14. DOI: $10.1071 /$ SR12075.

Kuligowski, K., Poulsen, T.G., Stoholm, P., Pind, N., Laursen, J. (2008) Nutrients and heavy metals distribution in thermally treated pig manure. Waste Management \& Research 26(4): 347-54. DOI: $10.1177 / 0734242 X 08090075$.

Larson, E.D., Fiorese, G., Liu, G., Williams, R.H., Kreutz, T.G., Consonni, S. (2009) Co-production of synfuels and electricity from coal + biomass with zero net carbon emissions: An Illinois case study. Energy Procedia 1(1): 4371-8. DOI: 10.1016/j.egypro.2009.02.251.

Lehmann, J., Gaunt, J. and Rondon, M. (2006) Bio-char sequestration in terrestrial ecosystems - A review. Mitigation and Adaptation Strategies for Global Change 11(2): 395-419. DOI: 10.1007/s11027-0059006-5.

Li, X., Rubæk, G.H., Müller-Stöver, D.S., Thomsen, T.P., Ahrenfeldt, J., Sørensen, P. (2017) Plant availability of phosphorus in five gasification biochars. Frontiers in Sustainable Food Systems 1: 1-12. DOI: $10.3389 /$ fsufs.2017.00002.

Liu, G., Larson, E.D., Williams, R.H., Kreutz, T.G., Guo, X. (2011) Making Fischer-Tropsch fuels and electricity from coal and biomass: Performance and cost analysis. Energy and Fuels 25(1): 415-37. DOI: $10.1021 / \mathrm{ef} 101184 \mathrm{e}$.

Mackay, J.E., Cavagnaro, T.R., Jakobsen, I., Macdonald, L.M., Grønlund, M., Thomsen, T.P., MüllerStöver, D.S. (2016) Evaluation of thermally processed sewage sludge as a soil P fertiliser. Environmental Science and Technology Submitted.

Maitlis, P.M. (2013) Greener Fischer-Tropsch Processes for Fuels and Feedstocks. First Edition. Maitlis, P.M. and Klerk de, A. (eds). Weinheim, Germany: WILEY-VCH Verlag GmbH \& Co. KGaA.

Matas Güell, B., Sandquist, J. and Sørum, L. (2012) Gasification of biomass to second generation biofuels: A review. Journal of Energy Resources Technology 135(1): 014001. DOI: 10.1115/1.4007660. 
Molino, A., Chianese, S. and Musmarra, D. (2016) Biomass gasification technology: The state of the art overview. Journal of Energy Chemistry 25(1): 10-25. DOI: 10.1016/j.jechem.2015.11.005.

Molino, A., Larocca, V., Chianese, S., Musmarra, D. (2018) Biofuels production by biomass gasification: A review. Energies 11(4). DOI: 10.3390/en11040811.

Müller-Stöver, D., Grønlund, M., Jakobsen, I., Ahrenfeldt, J., Holm, J.K., Hauggaard-Nielsen, H. (2014) Ashes from low-temperature gasification as sustainable phosphorus fertilizer. 4th Sustainable Phosphorus Summit. Montpellier, France, 1-3 September.

Narayan, V., Jensen, P.A., Henriksen, U.B., Glarborg, P., Lin, W., Nielsen, R.G. (2016) Defluidization in fluidized bed gasifiers using high-alkali content fuels. Biomass and Bioenergy 91: 160-74. DOI: 10.1016/j.biombioe.2016.05.009.

Nguyen, B.T., Lehmann, J., Kinyangi, J., Smernik, R., Riha, S.J., Engelhard, M.H. (2008) Long-term black carbon dynamics in cultivated soil. Biogeochemistry 89(3): 295-308. DOI: 10.1007/s10533-008-92209.

Nguyen, T.L.T., Hermansen, J.E. and Mogensen, L. (2013) Environmental performance of crop residues as an energy source for electricity production: The case of wheat straw in Denmark. Applied Energy 104: 633-41. DOI: 10.1016/j.apenergy.2012.11.057.

Omosun, A., Bauen, A, Brandon, N., Adjiman, C.S., Hart, D. (2004) Modelling system efficiencies and costs of two biomass-fuelled SOFC systems. Journal of Power Sources 131(1-2): 96-106. DOI: 10.1016/J.JPOWSOUR.2004.01.004.

Panopoulos, K.D., Fryda, L.E., Karl, J., Poulou, S., Kakaras, E. (2006) High temperature solid oxide fuel cell integrated with novel allothermal biomass gasification: Part I: Modelling and feasibility study. Journal of Power Sources 159(1): 570-85. DOI: 10.1016/J.JPOWSOUR.2005.12.024.

Porosoff, M.D., Yan, B. and Chen, J.G. (2016) Catalytic reduction of CO2by H2for synthesis of CO, methanol and hydrocarbons: Challenges and opportunities. Energy and Environmental Science 9(1): 62-73. DOI: $10.1039 / \mathrm{c} 5$ ee02657a.

Puerari, F., Bosio, B. and Heyen, G. (2014) Energy efficiency optimisation in different plant solutions for Methanol production from biomass gasification. Chemical Engineering Science 37: 301-6. DOI: 10.3303/CET1437051.

Røngaard Clausen, L. (2011) Design of Novel DME Methanol Synthesis Plants Based on Gasification of Biomass. Technical University of Denmark.

Rönsch, S., Schneider, J., Matthischke, S., Schlüter, M., Götz, M., Lefebvre, J., Prabhakaran, P., Bajohr, S. (2016) Review on methanation - From fundamentals to current projects. Fuel 166: 276-96. DOI: 10.1016/j.fuel.2015.10.111.

Rüegsegger, M. and Kast, M. (2018) Valorization of By-Products from Small Scale Thermal Gasification Valorization of By-Products from Small Scale Thermal - White Paper elaborated 2016-2018 under IEA Bioenergy, Task 33 Thermal Gasification of Biomass and waste. Fahrni, Switzerland: IEA Bioenergy Task 33 .

Ruiz, J.A.A., Juárez, M.C.C., Morales, M.P.P., et al. (2013) Biomass gasification for electricity generation: Review of current technology barriers. Renewable and Sustainable Energy Reviews 18. Pergamon: 174-83. DOI: 10.1016/j.rser.2012.10.021.

Samavati, M. (2018) Design and Analysis of Solid Oxide Electrolysis-Based Systems for Synthetic Liquid Fuels Production. Environmental Science. DOI: 10.3390/bios6010001.

Sansaniwal, S.K., Pal, K., Rosen, M.A., Tyagi, S.K. (2017) Recent advances in the development of biomass gasification technology: A comprehensive review. Renewable and Sustainable Energy Reviews 
72(December 2015): 363-84. DOI: 10.1016/j.rser.2017.01.038.

Shackley, S., Carter, S., Knowles, T., Middelink, E., Haefele, S., Sohi, S., Cross, A., Haszeldine, S. (2012) Sustainable gasification-biochar systems? A case-study of rice-husk gasification in Cambodia, Part I: Context, chemical properties, environmental and health and safety issues. Energy Policy 42: 49-58. DOI: 10.1016/j.enpol.2011.11.026.

Sikarwar, V.S., Zhao, M., Clough, P., Yao, J., Zhong, X., Memon, M.Z., Shah, N., Anthony, E.J., Fennell, P.S. (2016) An overview of advances in biomass gasification. Energy Environ. Science 9(10): 2939-77. DOI: 10.1039/C6EE00935B.

Singh, R.N., Singh, S.P., Balwanshi, J.B., Vishwavidhlya , D.S. (2014) Tar removal from producer gas: A review. Research Journal of Engineering Sciences 3(10): 16-22. DOI: 10.1002/elan.200603785.

Skoglund, N., Bäfver, L., Fahlström, J., Holmén, E., Renström, C. (2016) Fuel design in co-combustion of demolition wood chips and municipal sewage sludge. Fuel Processing Technology 141: 196-201. DOI: 10.1016/j.fuproc.2015.08.037.

Stoholm, P., Nielsen, R.G., Nielsen, M.B., Sander, B., Nørholm, N., Krogh, J., Henriksen, U.B., Qvale, B. (2007) LT-CFB forgasser $500 \mathrm{~kW}$ forsøg m.v. Slutrapport (Eng.: LT-CFB gasifier $500 \mathrm{~kW}$ experiment and more. Final report). 4833. Denmark: DFBT, Anhydro, FORCE Technology, Elsam Engineering, DTU MEK.

Stoholm, P., Nielsen, R.G., Sarbæk, L., Tobiasen, L., Fock, M.W., Richardt, K., Sander, B., Wolff, L., Henriksen, U.B. (2002) The Low Temperature CFB gasifier - Further test results and possible applications. In: Proceedings of the 12. European Biomass Conference, 2002, pp. 706-9.

Sun, L. and Smith, R. (2013) Rectisol wash process simulation and analysis. Journal of Cleaner Production (39): 321-8. DOI: 10.1016/j.jclepro.2012.05.049.

Sutton, D., Kelleher, B. and Ross, J.R.H. (2001) Review of literature on catalysts for biomass gasification. Fuel Processing Technology 73(3): 155-73. DOI: 10.1016/S0378-3820(01)00208-9.

Thompson, R., Thomsen, T.P. and Müller-Stöver, D. (2016) Plant phosphorus availability in thermally treated sewage sludge. In: 8th International Phosphorus Workshop (IPW8) 12-16 September 2016, Rostock (Germany), 2016. The Leibniz ScienceCampus Phosphorus Research Rostock.

Thomsen, T.P., Ahrenfeldt, J., Henriksen, U.B., Hauggaard-Nielsen, H., Holm, J.K. (2016) Closing the Loop - Utilization of Secondary Resources by Low Temperature Thermal Gasification. Technical University of Denmark, Lyngby, Denmark.

Thomsen, T.P., Hauggaard-Nielsen, H., Bruun, E.W., Ahrenfeldt, J. 2011) The potential of Pyrolysis Technology in climate change mitigation-influence of process design and-parameters, simulated in SuperPro Designer Software. Denmark. Forskningscenter Risoe. Roskilde, Denmark.

Thomsen, T.P., Ravenni, G., Holm, J.K., Ahrenfeldt, J., Hauggaard-Nielsen, H., Henriksen, U.B. (2015) Screening of various low-grade biomass materials for low temperature gasification: Method development and application. Biomass and Bioenergy 79: 128-44.

Thomsen, T.P., Sárossy, Z., Gøbel, B., Stoholm, P., Ahrenfeldt, J., Frandsen, F.J. (2017a) Low temperature circulating fluidized bed gasification and co-gasification of municipal sewage sludge. Part 1: Process performance and gas product characterization. Waste Management 66: 123-33. DOI: 10.1016/j.wasman.2017.04.028.

Thomsen, T.P., Hauggaard-Nielsen, H., Gøbel, B., Stoholm, P., Ahrenfeldt, J., Henriksen, U.B., MüllerStöver, D.S. (2017b) Low temperature circulating fluidized bed gasification and co-gasification of municipal sewage sludge. Part 2: Evaluation of ash materials as phosphorus fertilizer. Waste Management 66: 145-54. DOI: 10.1016/J.WASMAN.2017.04.043. 
Thomsen, T.P., Sárossy, Z., Ahrenfeldt, J., Henriksen, U.B., Frandsen, F.J., Müller-Stöve, D.S. (2017c) Changes imposed by pyrolysis, thermal gasification and incineration on composition and phosphorus fertilizer quality of municipal sewage sludge. Journal of Environmental Management 198: 308-18. DOI: $10.1016 /$ j.jenvman.2017.04.072.

Tijmensen, M.J.A., Faaij, A.P.C., Hamelinck, C.N., van Hardeveld, M.R.M. (2002) Exploration of the possibilities for production of Fischer Tropsch liquids and power via biomass gasification. Biomass and Bioenergy 23(2): 129-52. DOI: 10.1016/S0961-9534(02)00037-5.

Torres, W., Pansare, S.S. and Goodwin, J.G. (2007) Hot gas removal of tars, ammonia, and hydrogen sulfide from biomass gasification gas. Catalysis Reviews 49(4): 407-56. DOI: 10.1080/01614940701375134.

Vakkilainen, E., Kuparinen, K. and Heinimö, J. (2013) Large Industrial Users of Energy Biomass. Lappeenranta, Finland.

Valmet (2015) The World's Largest Biomass Gasifier Reduces Emissions at Vaskiluodon Voima. Online. https://www.valmet.com/media/articles/energy/the-worlds-largest-biomass-gasifier-reducesemissions-at-vaskiluodon-voima/

Valmet (n.d.) Valmet CFB Gasifier for Biomass and Waste. Online. https://www.valmet.com/energyproduction/gasification/

van der Meijden, C.M., Veringa, H.J. and Rabou, L.P.L.M. (2010) The production of synthetic natural gas (SNG): A comparison of three wood gasification systems for energy balance and overall efficiency. Biomass and Bioenergy 34(3): 302-11. DOI: 10.1016/j.biombioe.2009.11.001.

Venvik, H.J. and Yang, J. (2017) Catalysis in microstructured reactors: Short review on small-scale syngas production and further conversion into methanol, DME and Fischer-Tropsch products. Catalysis Today 285: 135-46. DOI: 10.1016/j.cattod.2017.02.014.

Vitasari, C.R., Jurascik, M. and Ptasinski, K.J. (2011) Exergy analysis of biomass-to-synthetic natural gas (SNG) process via indirect gasification of various biomass feedstock. Energy 36(6): 3825-37. DOI: 10.1016/j.energy.2010.09.026.

Williams, R.H., Liu, G., Kreutz, T.G., Larson, E.D. (2011) Coal and biomass to fuels and power. Annual Review of Chemical and Biomolecular Engineering 2(1): 529-53. DOI: 10.1146/annurev-chembioeng061010-114126.

Woolcock, P.J. and Brown, R.C. (2013) A review of cleaning technologies for biomass-derived syngas. Biomass and Bioenergy 52: 54-84. DOI: 10.1016/J.BIOMBIOE.2013.02.036.

Zhang, Z., Chen, B., Chen, A., Zhao, W. (2013a) Barriers to commercialization development of crop straw gasification technology in China and promoting policy design. Energy Sources, Part B: Economics, Planning, and Policy 8(3): 279-89. DOI: 10.1080/15567240903452071.

Zhang, Q., Deng, W. and Wang, Y. (2013b) Recent advances in understanding the key catalyst factors for Fischer-Tropsch synthesis. Journal of Energy Chemistry 22(1): 27-38. DOI: 10.1016/S20954956(13)60003-0.

Zwart, R., Heijden, S. Van Der, Emmen, R., Bentzen, J.D., Stoholm, P., Krogh, J. (2010) Tar Removal from Low-temperature Gasifiers. ECN-E-10-008. The Netherlands: ERA-NET Bioenergy. 